Discussion Paper No. 13-048

\title{
A Look at Both Sides of the Coin: Investigating the Protective and the Disclosure Effect of Patenting
}

Diana Heger and Alexandra K. Zaby

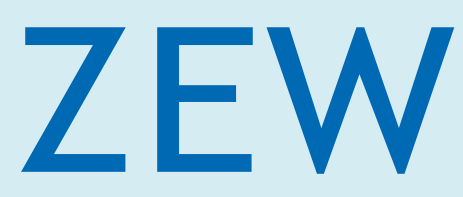

Zentrum für Europäische Wirtschaftsforschung $\mathrm{GmbH}$ Centre for European Economic Research 
Discussion Paper No. 13-048

\title{
A Look at Both Sides of the Coin: Investigating the Protective and the Disclosure Effect of Patenting
}

\author{
Diana Heger and Alexandra K. Zaby
}

Download this ZEW Discussion Paper from our ftp server:

http://ftp.zew.de/pub/zew-docs/dp/dp13048.pdf

Die Discussion Papers dienen einer möglichst schnellen Verbreitung von neueren Forschungsarbeiten des ZEW. Die Beiträge liegen in alleiniger Verantwortung der Autoren und stellen nicht notwendigerweise die Meinung des ZEW dar.

Discussion Papers are intended to make results of ZEW research promptly available to other economists in order to encourage discussion and suggestions for revisions. The authors are solely responsible for the contents which do not necessarily represent the opinion of the ZEW. 


\section{Non-technical summary}

We investigate the opposing impacts of two basic effects underlying the decision to patent: the protective and the disclosure effect. On the one hand, patents grant a temporary monopoly to an inventor, and thus, have a positive protective effect. On the other hand, patent law requires the full disclosure of all technological details concerning a patented discovery. As this transfer of enabling knowledge benefits rival firms the profits of the innovator may decrease. Hence, the patenting decision of an inventor has to balance the tradeoff between the benefits of temporary monopoly power, and the drawback of the disclosure. Naturally, the positive effect may be enhanced by stronger property rights while the negative effect is subject to the impact of the disclosure requirement. The presented analysis consists of a theoretical part which is a condensed version of Zaby (2010b) and an empirical test of the theoretical predictions.

The theoretical model introduces the patenting decision of a successful inventor into a market with vertically differentiated products. The two considered firms are asymmetric in their capabilities to adopt a new technology. Preceding the adoption decision an inventor faces the choice between a patent and secrecy to protect his discovery. A patent protects a given quality range from the entry of a rival. The main theoretical result is that the inventor will patent his invention whenever his technological headstart is moderate and that he will rather rely on secrecy whenever his technological headstart is high.

The empirical analyzes test predictions derived from the theoretical results. Empirical evidence supports the theoretical finding that the validity of a common economic intuition regarding the interplay of technological leadership and the propensity to patent is restricted to industry-specific characteristics: Our findings suggest that the propensity to patent increases with the extent of the technological leadership of an inventor only in industry sectors where the appropriability of an invention, given secrecy as the chosen protective measure, is low. This leads to an increase of the propensity to patent, as the positive protective effect of patenting gains weight. Furthermore, we find evidence that the strength of patent protection has a mitigating effect on the market entry threat perceived by an inventor, so stronger patents may lead to an increasing propensity to patent.

Summarizing, this paper provides a possible explanation for differing patenting rates observed across innovative industries. If, in an industry, new discoveries lacking legal protection may be quickly appropriated by competitors, firms opt for patent protection. The reason is that, in such industries, patent disclosure would not reveal additional essential information as the technological know-how diffuses as soon as an innovation is marketed. 


\section{Das Wichtigste in Kürze}

Der vorliegende Beitrag untersucht zwei gegenläufige, einer Patententscheidung zugrundeliegende Effekte: den Schutzeffekt sowie den Offenlegungseffekt eines Patents. Einerseits gewährt ein Patent seinem Inhaber ein temporäres Monopolrecht (Schutzeffekt), andererseits fordert das Patentgesetz die Offenlegung aller technologischen Details der patentierten Innovation (Offenlegungseffekt). Von diesem Wissenstransfer profitieren Konkurrenten, so dass der Gewinn des Erfinders aufgrund des Offenlegungseffekts sinken kann. Die Entscheidung zu Patentieren muss diese gegenläufigen Effekte gegeneinander abwägen: Die Vorteile eines temporären Monopolrechts gegen den Nachteil der verplichtenden Offenlegung. Offensichtlich wird der positive Schutzeffekt durch eine Erhöhung des Patentschutzes verstärkt, während der negative Offenlegungseffekt von den Auswirkungen einer Offenlegung beeinflusst wird. Diese Arbeit umfasst einen theoretischen sowie einen empirischen Teil, die sich mit den Wechselwirkungen beider Effekte beschäftigen. Der theoretische Teil stellt eine kompakte Zusammenfassung des Modells von Zaby (2010b) dar, im anschließenden empirischen Teil werden die Aussagen des theoretischen Modells empirisch beleuchtet.

Das theoretische Modell betrachtet die Patententscheidung eines erfolgreichen innovativen Unternehmens in einem Markt mit vertikal differenzierten Gütern. Die zwei betrachteten Unternehmen sind asymetrisch hinsichtlich ihrer Fähigkeit, die neue Technologie zu adaptieren. Zeitlich vor der Adaptionsentscheidung wählt das innovative Unternehmen eine adäquate Strategie, um sein intellektuelles Eigentum zu schützen: Patentieren oder Geheimhalten. Ein Patent schützt einen exogen gegebenen Teil des Produktraums vor dem Markteintritt eines Konkurrenten, erfordert allerdings die Offenlegung der Innovation. Das zentrale theoretische Ergebnis ist, dass ein innovatives Unternehmen eine Innovation dann patentiert, wenn sein technologischer Vorsprung gering ist, während es Geheimhaltung wählt, sobald sein technologischer Vorsprung einen kritischen Wert übersteigt.

Die anschließende empirische Analyse untersucht die theoretischen Aussagen. Die empirischen Ergebnisse unterstützen die Aussage des theoretischen Modells, dass die allgemeine Intuition über den Zusammenhang zwischen technologischem Vorsprung und der Patentneigung nur unter bestimmten, industriespezifischen Bedingungen Gültigkeit hat: Die Patentneigung steigt nur dann mit dem Grad des technologischen Vorsprungs an, wenn in einem Industriesektor die Appropriierbarkeit einer Erfindung über Geheimhaltung gering ist. In solch einem Fall steigt die Patentneigung, je höher der technologische Vorsprung ist, da der positive Schutzeffekt eines Patents gegenüber dem Offenlegungseffekt an Gewicht gewinnt. Desweiteren findet die vorliegende Arbeit empirische Evidenz dafür, dass die Stärke des Patentschutzes einen abschwächenden Effekt auf die Marktzutrittsdrohung hat, die ein innovatives Unternehmen subjektiv wahrnimmt. Hieraus kann man folgern, dass stärkerer Patentschutz zu einer steigenden Patentneigung führt.

Zusammenfassend präsentiert dieser Beitrag eine mögliche Erklärung für die beobachteten Unterschiede in den Patentraten zwischen innovativen Industrien. Wenn in einem Industriesektor Erfindungen ohne Patentschutz zeitnah von Wettbewerbern appropriiert werden können, werden innovative Unternehmen ihre Innovationen durch Patente schützen. 
Grund hierfür ist, dass in diesen Industriesektoren die Offenlegung des Patents keine zusätzlichen Informationen preisgibt, da das technologische Wissen mit der Markteinführung ohnehin offenbart wird. 


\title{
A look at both sides of the coin: investigating the protective and the disclosure effect of patenting
}

\author{
Diana Heger ${ }^{\ddagger *}$ and Alexandra K. Zaby ${ }^{\dagger *}$
}

\begin{abstract}
This paper presents a theoretical and empirical investigation of the two basic effects of patenting: the positive effect of temporarily mitigating competition, and the negative effect of mandatory disclosure of a patent application. Providing empirical evidence for the presented theoretical results we find that (i) a technological lead and the propensity to patent are negatively related as opposed to common intuition, (ii) in industries with imperfect appropriability in case of secrecy the extent of the technological lead is positively associated with the propensity to patent, and that (iii) the intensity of patent protection mitigates the competitive threat a patentee faces.
\end{abstract}

Keywords: patenting decision, disclosure requirement, patent scope, vertical product differentiation, IPC codes

JEL Classifications: L13, O14, O33, O34

\footnotetext{
${ }_{\ddagger}^{\ddagger}$ Centre for European Economic Research, L7, 1, D-68165 Mannheim. E-mail: heger@zew.de

${ }^{\dagger}$ University of Tuebingen, Department of Economics, Mohlstraße 36, D-72074 Tuebingen. E-mail: alexandra.zaby@uni-tuebingen.de

*The authors are grateful to Stuart Graham, Paul Jensen, Georg Licht, Cedric Schneider, Manfred Stadler as well as the participants of the European Association of Research in Industrial Economics (EARIE) 2011, the DRUID Summer Conference 2011 for valuable comments and discussions. All remaining errors are ours.
} 


\section{Introduction}

The fact that not every innovation is patented has long since been discussed in economic literature (see e.g. Horstmann et al. (1985), Anton and Yao (2004)). Empirical evidence points in the same direction: Arundel (2001) explicitly analyzes the relative importance of secrecy versus patents and finds that most firms rate secrecy as more valuable than a patent. As Cohen et al. (2000) find, one major reason for the firms to refrain from patenting is the disclosure requirement that is linked to a patent: The loss of a technological leadership caused by the required disclosure of proprietary knowledge may drive the propensity not to patent, as a patentee has to fear that the transfer of enabling knowledge induced by the mandatory publication of the patent application may benefit his rivals by facilitating a rapid catch-up. This, however, depends on the relevance of the technology embodied in the innovation for competitors. The main contribution of this paper is the investigation of the decision to patent in the context of the competitive environment of an innovative firm. The basic effects of intellectual property protection versus the mandatory disclosure of the innovative know-how drive the propensity to patent and affect the market entry threat perceived by an inventor. The decision of an inventor between patenting and the alternative protective strategy secrecy is analyzed analytically and empirically.

It is straightforward to assume that the considered effects of protection versus disclosure may vary throughout different industry sectors,${ }^{1}$ and given that there is strong empirical evidence that some industry sectors are characterized by higher patenting rates than others (Arundel et al., 1995), providing a possible explanation for this empirical evidence is a crucial part of our analyzes.

Patent law requires the full disclosure of all technological details concerning a patented discovery. This transfer of enabling knowledge benefits rival firms so that on the one hand, due to the disclosure effect of patenting, the profits of the innovator will decrease. ${ }^{2}$ On the other hand, patenting grants a temporary monopoly to the inventor and thus has a positive protective effect. Following this approach the patenting decision of an inventor has to balance the tradeoff between the benefits of temporary monopoly power, and the drawback of the complete disclosure of enabling knowledge. Naturally, the positive effect may be enhanced by stronger property rights while the negative effect is subject to the impact of the disclosure requirement. Our analysis consists of a theoretical part, which is a condensed version of Zaby (2010b), and an empirical test of the theoretical predictions. ${ }^{3}$

\footnotetext{
${ }^{1}$ For an investigation of the heterogenous costs of disclosure via patenting see Heger and Zaby (2013).

${ }^{2}$ Note that actually the impact of such a disclosure effect is subject to the implemented patent law. While in Europe a statutory research use exemption exists which allows the use of patented knowledge for research purposes, in other countries, such as the U.S. a statutory research use exemption does not exist. In terms of the underlying theoretical model the lack of a research use exemption would mitigate the impact of the disclosure effect.

${ }^{3}$ The empirical analyzes presented here in some parts build on chapter 3 of Alexandra Zaby's dissertation, see Zaby (2010a).
} 
The theoretical model introduces the patenting decision of a successful inventor into a market with vertically differentiated products. The two firms considered are asymmetric in their capabilities to adopt a new technology. Preceding the adoption decision the inventor faces the choice between a patent and secrecy to protect his discovery. A patent protects a given quality range from the entry of a rival. ${ }^{4}$ The main theoretical result is that the inventor will patent his invention whenever his technological headstart is moderate and that he will rather rely on secrecy whenever his technological headstart is high. The latter is due to the fact that in this case the positive protective effect of a patent is outweighed by the negative effect of the required disclosure.

The crucial requirement for the empirical implementation of this theoretical model is the combination of information on innovative activity of firms (including intellectual property protection strategies) with information on the competitive environment as perceived by the firms. Such data is provided by the Mannheim Innovation Panel (MIP), which is the German contribution to the Community Innovation Survey (CIS). Several questions concerning the competitive environment are included in the MIP 2005. To reflect the strength of the protective effect, the theoretical model implements varying degrees of patent scope. For our empirical analyzes, we use a measure based on the International Patent Classification (IPC) following Lerner (1994) and additionally apply a more traditional measure of patent scope based on forward citations.

Our empirical analyzes show that the common economic intuition that the propensity to patent increases with the extent of the technological leadership of an inventor, can only be confirmed for industry sectors in which the appropriability of innovative know-how is low when relying on secrecy. In such a setting an inventor's technological headstart is reduced whenever he relies on secrecy leading to an increase of the propensity to patent as the positive protective effect of patenting gains weight. Furthermore, we find evidence that the strength of patent protection has a detrimental effect on the market entry threat perceived by the inventor, so stronger patents may lead to an increasing propensity to patent.

Several empirical studies aim at analyzing the propensity to patent. König and Licht (1995) investigate the importance of patents compared to non-legal appropriation methods of research output and find that non-legal intellectual protection tools are more effective than patents. In a direct comparison of the use of patents versus secrecy, Hussinger (2006) finds that patents are effective to protect innovations, i.e. commercialized inventions, while secrecy is rather important for inventions which are in the pre-market phase. Arundel and Kabla (1998) calculate the sales-weighted patent propensity rates for 19 industries. They find that only four industry sectors reveal patent propensities which exceed $50 \%$.

We contribute to this literature by explicitly "looking at both sides of the coin" as we divide the impact of patenting into a protective and a disclosure effect. Accounting for the consequences that patenting has on the competitive environment further allows us to gain deeper insights on the driving forces behind the decision to patent.

\footnotetext{
${ }^{4}$ For a thorough analysis of the optimal patent design regarding "leading breadth" see Denicolò and Zanchettin (2002).
} 
The rest of the paper is organized as follows. In section 2 we present a brief version of the underlying theoretical model. Section 3.1 then states the predictions summarizing the theoretical results and presents their empirical implementation. The following section 3.2 describes the data set and sample definition whereas section 3.3 presents variable definitions and descriptive statistics. Section 3.4 presents our empirical results. Section 4 concludes.

\section{The theoretical model}

The model presented in this section is a condensed version of the model presented in Zaby (2010b). In a setting of dynamic vertical product differentiation, a successful inventor decides between a patent or secrecy in order to protect his invention, before determining the timing of his market entry. The decisions of the inventor are modeled in a three stage game.

On the first stage, the inventor - denoted by subscript $i$ - chooses the protection method for his discovery. His strategy is either to patent or to keep his invention secret. On the second stage, firms choose whether to market a product of low quality or a product of high quality given the inventor's protection decision. On the third stage, firms compete in prices. The game is solved by backward induction.

One crucial assumption of the model is the dynamic evolvement of product quality. Following Dutta et al. (1995) and Hoppe and Lehmann-Grube (2001) we assume that investing more time in research activities suffices to improve the quality of the new technology over time. More precisely, the quality of the invention, $x$, increases by one unit in every period without involving any further research costs. Thus, the time the inventor needs in order to reach quality $x$ is given by

$$
t_{i}(x)=x,
$$

implying that the investment of $t_{i}(\bar{x})=\bar{x}$ periods of time enables the inventor to adopt the quality level $\bar{x}$.

To capture the fact that the inventor has a technological headstart compared to his rival, it is further assumed that at the time of the invention $(t=0)$ he has a technological lead in height of $\gamma$ which is common knowledge. This means that the non-inventor needs to invest $\gamma$ periods more than the inventor to reach the same quality level, i.e. his research time is given by $t_{j}(x)=x+\gamma$. Whenever the inventor patents, he loses his lead so that $\gamma=0$.

If the inventor chooses secrecy to protect his invention, his intellectual property is not perfectly appropriable. Subject to the inventor's competitive environment part of his technological leadership is lost in the absence of legal protection. We measure this imperfect appropriability in the case of secrecy by the parameter $\lambda$ and distinguish the initial headstart of the inventor, $\tilde{\gamma}$, from his effective headstart, $\gamma$. In case of secrecy, the extent of the technological lead of the inventor at any point in time $t>0$ will differ from his initial headstart if $\lambda>0$. Consequently, the extent of the inventor's effective technological lead is defined by $\gamma \equiv \tilde{\gamma}(1-\lambda)$ meaning that the non-inventor profits from 
decreasing appropriability as his research time

$$
t_{j}(x)=x+\tilde{\gamma}-\lambda \tilde{\gamma}=x+\gamma
$$

is shortened by $\lambda \tilde{\gamma}$ for $\lambda>0$.

\subsection{Price competition}

Subsequent to the protection decision on the first stage and the quality decisions of the firms on the second stage of the game, firms compete in prices. During the temporary monopoly the first adopter earns monopoly profits $\pi_{m}$ per period. The entrance of the late adopter changes the market structure to an asymmetric duopoly where the firm offering the lower quality, i.e. the first adopter, earns $\pi_{l}$ per period and the firm offering the higher quality, i.e. the late adopter, realizes profits $\pi_{h}$ per period, with $\pi_{m}>\pi_{h}>\pi_{l}$.

The entry date of the early adopter is denoted by $t_{l}$ and the point in time when the late adopter enters with a higher quality by $t_{h}$, respectively. All future profits are discounted with the interest rate $r>0$.

An early adopter's overall profit consists of two parts: the monopoly profits he realizes from his adoption in $t_{l}$ until the second firm enters in $t_{h}$ and the subsequent duopoly profits

$$
L\left(x_{l}\right)=\int_{t_{l}}^{t_{h}} e^{-r t} \pi_{m} d t+\int_{t_{h}}^{\infty} e^{-r t} \pi_{l} d t .
$$

A late adopter earns duopoly profits $\pi_{h}$ per period starting with his entry into the market in $t_{h}$ with a high quality $x_{h}$

$$
H\left(x_{h}, x_{l}\right)=\int_{t_{h}}^{\infty} e^{-r t} \pi_{h} d t .
$$

\subsection{Quality choices}

On the second stage, the late adopter $H$ has to decide when to adopt the new technology after the early adopter $L$ has already adopted the low quality $x_{l}$. Optimization of equation (4), with respect to the quality level $x_{h}$ yields the optimum differentiation strategy given the early adopter's quality decision, $x_{l}$,

$$
x_{h}^{*}=x_{l}+\frac{1}{r} .
$$

The crucial aspect in deriving the optimum quality choices is the distinction of the respective research time functions of the inventor and the non-inventor in the two possible scenarios: In scenario $(I)$, the inventor is the early adopter and his rival is the late adopter. Thus, the respective research time functions are $t_{i}\left(x_{l}\right)=x_{l}$ and $t_{j}\left(x_{h}^{*}\right)=$ $x_{l}+1 / r+\gamma$. Inserting the latter into equation (4) yields the overall profits of the noninventor, $H_{j}\left(x_{l}\right)$. The innovator as early adopter anticipates the optimum differentiation 
strategy of his rival as well as his research time. Inserting $x_{h}^{*}$ and $t_{j}\left(x_{h}^{*}\right)$ into equation (3) yields the overall profit of the inventor as early adopter, $L_{i}\left(x_{l}\right)$. Optimization of $L_{i}\left(x_{l}\right)$ with respect to $x_{l}$ then yields the profit maximizing adoption quality for the inventor, $x_{l}^{*}$.

In scenario $(I I)$, the non-inventor is the first adopter. Therefore the research time functions change to $t_{j}\left(x_{l}\right)=x_{l}+\gamma$ for the non-inventor and $t_{i}\left(x_{h}^{*}\right)=x_{l}+1 / r$ for the inventor as late adopter. Following the same manner as in scenario (I), the respective overall profits of the non-inventor as early adopter, $L_{j}\left(x_{l}\right)$, and the inventor as late adopter, $H_{i}\left(x_{l}\right)$, can be derived.

$<$ Insert figure 1 about here. $>$

In figure 1, the dashed lines represent the alternative overall profits the inventor can realize while the solid lines represent those of the non-inventor.

Whenever $L_{u}>H_{u}, u=i, j$, a firm prefers to be the first adopter and whenever $H_{u}>L_{u}$ a firm prefers to wait until a rival has entered and then enter as second adopter.

The quality choices of the inventor and his rival depend on the inventor's protection decision on the first stage of the game meaning that the possible cases secrecy and patent have to be distinguished. To avoid confusion, choice variables will carry the superscript $S$ if the inventor chooses secrecy and the superscript $P$ if he patents his invention.

According to the profit functions in Figure 1, given secrecy both firms prefer to be the first adopter at their profit maximizing entry date $t_{u}^{*} \equiv t\left(x_{u}^{S *}\right), u=i, j$, as this would maximize their overall profits $L_{u}\left(t_{u}^{*}\right), u=i, j$. Since both anticipate that the other will follow the adoption strategy adopt first in the area where $L_{u}>H_{u}$, none of them is actually able to reach his profit maximizing quality level. Both have the incentive to preempt the other until one reaches the adoption date at which early and late adoption yield the same profits, which is the case at the intersection point of both curves, $t^{I}$, where $L_{u}\left(t^{I}\right)=H_{u}\left(t^{I}\right), u=i, j$. Therefore, the loser of the race for being the first will be the firm that reaches this intersection point first when moving backwards from $t_{u}^{*}$, $u=i, j$. A comparison of the intersection points of the inventor and the non-inventor shows that if both firms follow the strategy adopt first, the inventor will always win the preemption race by adopting at $t_{j}^{I}$, the intersection point of the curves $H_{j}$ and $L_{j}$. At this point, the non-inventor has no incentive to continue the race for being the first by preempting the inventor as $L_{j}\left(t^{I}-\epsilon\right)<H_{j}\left(t^{I}\right)$. We thus state

Result 1 If the inventor chooses to keep his invention secret, he adopts first offering the low quality and the non-inventor is the late adopter offering the high quality.

If the inventor chooses to patent his invention, a given range of quality levels, which we 
denote as the height of the patent $\phi$, are protected by the patent. ${ }^{5}$ As a consequence the non-inventor can only enter the market with a quality that exceeds the protected range. This positive effect of patenting is accompanied by the drawback that the inventor loses his technological lead due to the disclosure requirement, $\gamma=0$. The inventor has an incentive to patent in every situation where he is not able to adopt his profit maximizing quality level, $x_{l}^{*}$. In this case, a patent mitigates the threat of entry perceived by the inventor: With a patent a given range of product space is protected from the entry of a rival so that the inventor can postpone his entry long enough to realize a higher product quality, $x_{i}^{P}>x_{i}^{S}$.

We distinguish three patent types according to their protectional degree: weakly protective patents, strongly protective patents and delaying patents. Patents of height $\phi \in] x_{i}^{S}, x_{i}^{*}[$ are defined as weakly protective patents protecting the quality range up to $\phi$. Patents of height $\phi \in\left[x_{i}^{*}, x_{h}^{*}\right.$ [ are defined as strongly protective patents as they allow the inventor to reach his profit maximizing quality $x_{i}^{*}$. Both patent types modestly mitigate the threat of entry as they still admit the non-inventor to follow his best differentiation strategy, $x_{j}^{*}>\phi$. The strongest protectional degree is reached with $d e-$ laying patents. They are defined as patents of height $\bar{\phi} \geq x_{h}^{*}$ so that they affect the differentiation strategy of the non-inventor: he is forced to postpone adoption further into the future so a patent effectively mitigates the threat of entry.

Given that the inventor patents his invention, three alternative unique Nash equilibria in the subgame patent exist, depending on the strength of protection. They are summarized as our

Result 2 If the inventor chooses to patent his invention the subgame patent has three alternative unique and stable Nash Equilibria.

(i) With a weakly protective patent the inventor adopts the quality $\phi$ and the noninventor can follow his profit maximizing strategy. The perceived threat of entry is weakly mitigated.

(ii) With a strongly protective patent the inventor adopts his profit maximizing quality $x_{i}^{*}$ and the non-inventor can follow his profit maximizing strategy as well. The perceived threat of entry is modestly mitigated.

(iii) With a delaying patent the inventor adopts the quality $x_{i}^{*}$ and the non-inventor is forced to wait until he reaches the quality $\bar{\phi}+\epsilon$. The perceived threat of entry is strongly mitigated.

Thus, patenting reduces the threat of entry perceived by the inventor: The protective effect of a patent broadens the inventor's possible strategy choices, providing him with the possibility to realize a quality level which yields higher profits than in the case that he chooses secrecy. The extent of this effect is subject to the intensity of patent protection.

\footnotetext{
${ }^{5}$ In denoting the strength of patent protection as a patent's height, we follow van Dijk (1996). Note though, that as the distinction of the intensity of patent protection into breadth and height cannot be implemented empirically, we refer to patent scope in our empirical analysis.
} 


\subsection{The patenting decision}

On the first stage of the game, the inventor decides whether to patent or to keep his invention secret. The subgame perfect Nash equilibrium of the three stage game can be derived by comparing the inventor's alternative payoffs subject to the chosen protection mechanism: he will choose to patent whenever this yields higher profits than keeping the invention secret. Due to the disclosure requirement, the inventor has to consider the tradeoff between the positive and the negative effect of patenting.

The positive protective effect of a patent can be isolated by calculating the difference between the inventor's profit with and without a patent, ignoring the disclosure effect by keeping $\gamma>0$. By patenting the inventor is able to choose the higher quality $x_{i}^{P}$, while with secrecy he realizes $x_{i}^{S}$, where $x_{i}^{P}>x_{i}^{S}$. This defines

$$
\Delta^{+}=\left.L_{i}\left(x_{i}^{P}\right)\right|_{\gamma>0}-\left.L_{i}\left(x_{i}^{S}\right)\right|_{\gamma>0}
$$

as the positive protective effect of patenting. This positive effect is opposed by the negative disclosure effect. Due to the disclosure requirement linked to a patent the inventor loses his lead meaning that technically speaking the technological headstart of the inventor, $\gamma$, becomes zero. Consequently, as the non-inventor is now able to enter at an earlier point in time, $t_{j}^{P}(x)=x$, instead of $t_{j}^{S}(x)=x+\gamma$, the duration of the monopoly of the patent holder is narrowed. This negative patent effect can be measured by the difference between the profit of the inventor with and without a technological lead,

$$
\Delta^{-}=\left.L_{i}\left(x_{i}^{P}\right)\right|_{\gamma>0}-\left.L_{i}\left(x_{i}^{P}\right)\right|_{\gamma=0} .
$$

Combining the protective and the disclosure effect yields the overall effect that patenting has on the profit of the inventor, $\Delta_{P}=\Delta^{+}-\Delta^{-}$. Inserting equations (6) and (7) this total patent effect can be derived as

$$
\Delta_{P}=\left.L_{i}\left(x_{i}^{P}\right)\right|_{\gamma=0}-\left.L_{i}\left(x_{i}^{S}\right)\right|_{\gamma>0} .
$$

Whenever the total patent effect $\Delta_{P}$ is positive, the protective effect overcompensates the disclosure effect and the inventor has an incentive to patent as this increases his overall profits.

$$
<\text { Insert figure } 2 \text { about here. }>
$$

Figure 2 depicts the total patent effect for strongly protective patents. Obviously the total patent effect $\Delta_{P}$ takes positive as well as negative values. The intersection point of the $\Delta_{P}$ - curve with the x-axis defines a critical value of the technological lead, $\gamma^{P}$. For $\gamma=\gamma^{P}$ the protective and the disclosure effect cancel each other out. If the effective technological lead is small, $\gamma<\gamma^{P}$, the protective effect dominates the disclosure effect and the inventor profits from patenting his basic invention. If the technological lead 
exceeds the critical value $\gamma^{P}$ the disclosure effect outweighs the protective effect so that the total patent effect is negative and the inventor prefers to keep his invention secret. This gives us

Result 3 The patenting decision of the inventor crucially depends on the extent of his technological headstart. He will choose to

(i) patent if his technological lead is small $\gamma^{P} \geq \gamma$,

(ii) keep his invention secret if his technological lead is high, $\gamma>\gamma^{P}$.

The value of $\lambda$ influences this result indirectly: a decrease of the appropriability via secrecy leads to an increasing propensity to patent as the effective technological lead, $\gamma \equiv \tilde{\gamma}(1-\lambda)$, declines in the absence of patent protection. Thus, even a large initial technological headstart diminishes in case of imperfect appropriability, meaning that the protective effect of the patent will outweigh the disclosure effect as the latter is weakened due to a low value of the appropriability parameter. This leads us to

Result 4 The propensity to patent increases whenever the appropriability via secrecy, $\lambda$, decreases.

Intuitively, intensifying the strength of patent protection should have the same effect. For weakly protective patents this is quite straightforward: a change of patent height has no impact on the disclosure effect of a patent, but influences its protective effect. Thus, a rise of $\phi$ would result in an upward shift of the $\Delta_{P}$ - curve in Figure 2 shifting the critical value $\gamma_{P}$ to the right so that the parameter space in which the inventor decides to patent would grow larger. With a strongly protective patent the inventor already realizes his profit maximizing quality level and a further increase of patent height has no influence on the protective effect of the patent, leaving the propensity to patent unchanged. The case is different for delaying patents. They have a strong mitigating effect on the threat of entry as they postpone the non-inventor's entry date further into the future leading to a rise of the profit of the inventor due to a longer duration of his monopoly. This again results in an increase of the protective effect of patenting which raises the propensity to patent. This gives us our final theoretical

Result 5 In the case of weakly protective and delaying patents, the propensity to patent increases whenever patent height increases.

\section{Empirical investigation}

Building on these theoretical results we now turn to the empirical investigation of the decision to patent. Our analysis accounts for both considered effects of patenting: the protective and the disclosure effect. In a first step, we will condense the proposed interdependencies into three predictions which we will then test empirically. Second, we describe the data set, its extensions and the sample definition which we will use to analyze the predictions. Third, we explain the variables we use to test our predictions empirically, and finally, present our results. 


\subsection{Theoretical predictions and their empirical implementation}

The disclosure and the protective effect of patenting are driven by the three parameters extent of the technological lead, $\gamma$, appropriability via secrecy, $\lambda$, and intensity of patent protection, $\phi$. Naturally, it is not possible to completely disentangle the protective and the disclosure effect in empirical terms, so our analysis is to be understood as distinguishing situations in which both effects have an impact, but one overcompensates the other.

Before an innovative firm decides to patent it evaluates the tradeoff between the protective and the disclosure effect inherent in patenting. Hence, the best way to implement and test both effects empirically, would be to relate them to the propensity to patent. As stated before, the disclosure effect is driven by the technological lead and its interplay with the imperfect appropriability caused by specific product market characteristics, whereas the protective effect of patenting is contingent on increases in patent scope. In the theoretical model, patent scope is known to the firm when deciding on patenting. In the empirical analyzes, we are not able to directly link patent scope to the propensity to patent, as the measures concerning patent scope, which will be described in section 3.3, can only be calculated ex post. During the filing process there is a certain chance that changes to patent applications are made up to their publication, a fact which affects patent scope. Nevertheless, the patentee has an ex ante assessment of the scope of the potential patent, and this ex ante evaluation of the protective effect influences his decision to patent. In order to grasp this empirically, our analyzes concerning the protective effect draw on a different cohesion: as the protective effect of a patent influences the competitive environment on the product market by mitigating the threat of entry of competitors, we test whether the scope of (lagged) patent applications is negatively correlated to the threat of entry as perceived by the firms. Because of the close relation between the protective effect of patenting and the threat of entry, our results allow inferences on whether patent scope impacts on the propensity to patent. Our approach can thus be specified as follows: We will first empirically investigate the impact of the disclosure effect on the patenting decision and will then examine the theoretical results regarding the protective effect of a patent.

According to the theoretical model, the disclosure effect's strength is subject to the technological lead of the inventor. Hence, we focus on the relation between the actual technological lead - which is the result of the interplay between the initial lead and its potential reduction due to imperfect appropriability - and the propensity to patent. An increasing technological lead strengthens the disclosure effect of patenting while the protective effect remains unchanged. Following result 3 we suppose that the relation between the technological lead and the propensity to patent is negative and state

Prediction 1 The higher the technological lead, the lower is the inventor's propensity to patent.

The theoretical model assumes that the effectiveness of appropriating the returns from an innovation in the case of secrecy is exogenously given. Decreasing appropri- 
ability weakens the alternative "secrecy" such that the propensity to patent will be high whenever appropriability is low, i.e., $\lambda$ is high. This gives us

Prediction 2 The propensity to patent is high whenever the initial technological lead is reduced by a low appropriability in the case of secrecy.

To translate these predictions into an estimation equation we come back to the definition of the effective technological lead stated in the theoretical model:

$$
\gamma \equiv \tilde{\gamma}-\lambda \tilde{\gamma}
$$

which is included in the following estimation equation

$$
P=\beta_{1}+\beta_{2} T L+\beta_{3} A P P+\beta_{4} T L * A P P+\text { Controls }
$$

where $P$ denotes the patenting decision, $T L$ the (initial) technological lead and $A P P$ the appropriability given secrecy. In line with the theoretical findings, we conjecture a negative influence of the technological lead $(T L)$ and a positive effect of the interaction term of $T L$ and $A P P{ }^{6}$ As in the theoretical model appropriability has no direct effect on the propensity to patent, we expect to find no significant effect of $A P P$ empirically.

The final prediction focuses on the protective effect which is subject to the extent of patent protection, i.e. the scope of a patent. From result 2 we know that patenting has an impact on the competitive threat. Again this impact entails the two opposing effects of disclosure and protection: If an inventor chooses to patent, the mandatory disclosure of the invention enables his rival to enter the market at an earlier point in time, i.e. the inventor loses his lead. This effect is opposed by the protective effect of a patent which may postpone the entry date of competitors due to the fact that they need additional time to develop a product quality that lies just outside the patent protected range. According to result 2 the latter effect should be stronger, the higher the level of patent protection is. Combining this finding with result 5 we propose our final

Prediction 3 The threat of entry decreases with the intensity of patent protection, i.e. patent scope. Thus, the propensity to patent increases when patent scope increases.

This translates into the following empirical model

$$
T O E=\beta_{1}+\beta_{2} T L+\beta_{3} A P P+\beta_{4} P S+\text { Controls, }
$$

where TOE is the threat of entry, and $P S$ reflects the extent of patent scope. For a definition of $T L$ and $A P P$ see the previous equation. In accordance with the theoretical model, patent scope and technological lead should have a negative effect on the perceived intensity of the threat of entry.

\footnotetext{
${ }^{6}$ For the reasoning behind this interrelation, recall that $\lambda \tilde{\gamma}$ decreases the effective headstart $\gamma$ and that the overall patent effect increases whenever $\gamma$ decreases, see Figure 2.
} 


\subsection{Data set and sample definition}

The basis for the empirical analysis is the Mannheim Innovation Panel (MIP) of the year 2005. The MIP is an annual survey which is conducted by the Centre for European Economic Research (ZEW) Mannheim. The aim of the survey is to provide a tool to investigate the innovation behavior of German manufacturing and service firms. Regularly - currently every two years - the MIP is the German contribution to the Community Innovation Survey (CIS). In 2005, the survey additionally contained an investigation of firms' perception of their competitive situation. Thus, questions regarding the characteristics and the importance of specific competitive factors like price or quality as well as questions concerning the perceived competitive situation were included. To capture patent scope we merge patent information provided by the European Patent Office $(\mathrm{EPO})^{7}$, by condensing the EPO data to the firm level. ${ }^{8}$ We identified only few firms that stated to hold a patent in the MIP survey but had no equivalent entry in the EPO data. Due to the missing information we dropped these observations.

In a next step we translate the crucial assumptions of the theoretical model into empirical terms. Most importantly, the world in which the model and its results are valid is one of innovative firms and vertically differentiated products. Thus, in order to test our predictions, we first of all restrict our sample to innovative firms, i.e. we exclude firms which did not launch a new product or process within the period 2002 to 2004 . Furthermore, we only include firms with a competitive situation characterized by quality competition. In the 2005 survey, one question was included which refers to a characterization of the competitive situation on the main product market as perceived by the questioned firm. The firms were asked to rank the following choices according to their importance: quality, price, technological advance, advertisement, product variety, flexibility towards customers. In our sample, we keep all observations where firms indicated that quality is the most, second or third most important feature of their competitive situation. Finally, as patents are the only legal protection measure requiring the disclosure of the technological know-how embodied in an invention, we exclude all other legal protection measures like trademarks from the sample and only include firms which indicate that they either use patenting or secrecy (or both). Our empirical investigations are based on 771 firms.

\subsection{Variable definition and descriptive statistics}

In the following, we will describe how we define the core variables of the two estimations: the inventor's patenting decision and competitors' timing of entry decisions.

The dependent variable of the propensity to patent estimation is patenting which is a dummy variable indicating whether a firm uses patenting to protect its intellectual property. In our data set, about $60 \%$ of the firms applied for a patent in the relevant period (see Table 2).

\footnotetext{
${ }^{7}$ The merge was conducted by Thorsten Doherr, ZEW, Mannheim, using a computer assisted matching algorithm on the basis of firm names and addresses.

${ }^{8}$ We take all patent applications which have been filed by the sampled firms up to the year 2003.
} 
The central variables of the propensity to patent estimation are technological leadership and the appropriability via secrecy. Both are not straightforward to implement empirically. In accordance with the definition in the theoretical model, we define technological leadership by the variable temporal headstart over competitors. Respondents indicated whether the importance of a temporal headstart was high, medium or low and our dummy variable indicates whether a respondent chose high.

Next, we turn to the empirical definition of the appropriability of the innovation given secrecy. Imperfect appropriability may arise through different channels such as unintended knowledge spillover, absorptive capacity of competitors, easiness of reverse engineering, or technological proximity. We conjecture that - if firms' competitive environment is characterized by easy-to-substitute products - the relevance of the embodied technology for competitors is high in the respective industry. Industries with easy-tosubstitute products embody any of the four channels of imperfect appropriability identified above. If products are easily substituted technological proximity, and the easiness of reverse engineering are supposed to be high. At the same time, unintended knowledge spillover can easily be absorbed by competing firms. Thus, the appropriability of innovative know-how in the absence of legal protective measures is low. Hence, we conclude that imperfect appropriability can be proxied by substitutability and construct a dummy variable which has unit value if a firm's relevant market is characterized by easy-to-substitute products to capture imperfect appropriability. From the theoretical model we know that the technological leadership of a firm may be reduced due to imperfect appropriability. To implement this fact in our empirical analysis we create an interaction term $(T L * A P P)$.

Furthermore, we control for several factors that may influence innovation activities, like firm size, human capital, R\&D intensity, R\&D cooperation, public R\&D subsidies and diversification, firm location (eastern Germany) and industry affiliation according to NACE codes. We also reflect the structure and the characteristics of a firm's relevant market. We control for the number of competitors, the geographical dimension of the relevant market, characteristics of the product life cycle (products become obsolete rapidly) and quick changes in production technology. Table 2 provides an overview of the variables, their descriptive statistics and a short description of how they were defined.

Regarding the second estimation of the competitors' entry decision we try to capture the threat of entry (TOE) as perceived by the inventor. We refer to a firm's statement whether its market position is threatened by the entry of new rivals, which is ranked on a 4-digit Likert scale (fully applies, rather applies, hardly applies, does not apply). This ordered variable is our indicator showing to what extent the protective effect of a patent relates to the threat of market entry perceived by the inventor: we assume that firms rank the threat of entry higher, the sooner a rival may be able to enter the market. Thus, if a firm expects that the time until a rival enters is rather short, it should rank the variable threat of entry higher than in a case when it assumes that the rival's market entry will take place at a later point in time. 
For the investigation of the protective effect, we need to define patent scope in empirical terms. For our measure of patent scope we follow Lerner (1994) and refer to the International Patent Classification (IPC) codes. The classification codes relate a patent into specific technology clusters which vary in their aggregational level. As a robustness check for this measure, we use a firm's average number of patent citations per patent application. $^{9}$

Table 1: International Patent Classification (IPC) Code of the European Patent Office

\begin{tabular}{ccccc}
\hline Section & Class & Subclass & \multicolumn{2}{c}{ Group } \\
\hline & & & Main Group & Subgroup \\
A & 01 & B & $33 / 0$ & $33 / 08$ \\
\hline
\end{tabular}

Lerner (1994) argues that patent scope can be captured by a variation of the first four digits of the IPC codes assigned to a patent (see also Austin, 1993). He used several alternative approaches to validate this implementation. His argumentation mainly built on a regression of the number of patent citations on the number of variations in the assigned IPC codes; additionally, he conducted interviews with 12 intellectual property attorneys. All validation procedures revealed that patent scope can be appropriately implemented by variations in IPC codes.

For the empirical definition of weakly, strongly protective and delaying patents, we need a more detailed differentiation than that proposed in Lerner (1994). In order to capture the different levels of patent scope we distinguish between variations of IPC codes at the class, the subclass or the group level. ${ }^{10}$ The IPC Guide gives a quite clear statement on the relation between the IPC code and the scope of the respective patent.

The titles of sections, subsections and classes are only broadly indicative of their content and do not define with precision the subject matter falling under the general indication of the title. In general, the section or subsection titles very loosely indicate the broad nature of the scope of the subject matter to be found within the section or subsection, and the class title gives an overall indication of the subject matter covered by its subclasses. By contrast, it is the intention in the Classification that the titles of subclasses [...] define as precisely as possible the scope of the subject matter covered thereby. The titles

\footnotetext{
${ }^{9}$ Patent scope is often reflected by patent (forward) citations (e.g. Hall et al., 2005, Harhoff et al., 2003). The caveat of patent citations is that they only evaluate patent scope ex post. We assume that the inventor anticipates the scope of his patent, but that it is revealed to the empiricist only after several years.

${ }^{10}$ To examine whether this distinction of variations in the IPC codes is an appropriate measure for patent scope we use the regression-based robustness check implemented by Lerner (1994). We use patent data from 1995 and its citations up to 2005 to escape the problem of recentness. Our Poisson regressions reveal two significant effects: A strongly positive effect of our delaying patent indicator and a negative effect for the indicator of weakly protective patents.
} 
of main groups and subgroups [...] precisely define the subject matter covered thereby $[\ldots]$

(§68, IPC Guide)

In line with the above quote, since "the class title gives an overall indication of the subject matter covered by its subclasses"and as variations at the sectional level (including subsections), only "very loosely indicate the scope" of the respective patent, we define the alternative patent scopes weakly protective, strongly protective and delaying patents starting with variations at the class level. Thus, we implement the alternative patent scopes from our theoretical model as follows: Whenever a classification symbol differs on the level of classes or subclasses, we characterize the respective patent as delaying. We define a patent as strongly protective, if the IPC codes vary in groups and as weakly protective, if the IPC codes differ in subgroups. Additionally, all patents with a single IPC code are classified as weakly protective patents. For every firm we count all delaying, strongly and weakly protective patents and divide them by the number of employees as we assume that larger firms tend to have larger patent portfolios. For further robustness checks, we move the frontiers of each category.

Again, we control for several factors that may influence our dependent variables. Most of the control variables coincide with those of the propensity to patent-estimation. We further include capital intensity as a measure of market entry barriers and an indicator for market novelty. The respective descriptions can again be found in table 2 .

\subsection{Empirical results}

This section is split into two parts according to which effect of patenting we focus on. First we discuss the results regarding the disclosure effect and evaluate prediction 1 and 2 focussing on the propensity to patent. Second, we present the results with respect to the protective effect which assess prediction 3 looking at the competitors' entry decision.

\section{The disclosure effect of patenting}

The theoretical model predicts that firms decide to either patent or keep their invention secret taking into account the technological lead and its potential reduction due to imperfect appropriability via secrecy. We test predictions 1 and 2 concerning the disclosure effect of patenting by estimating a probit model with robust standard errors displaying marginal effects evaluated at the sample means with standard errors calculated using the delta method. This estimation also includes an interaction term of technological lead and appropriability in order to test prediction 2. We calculate its marginal effect using the method proposed by Ai and Norton (2003) and present a graphical analysis of its marginal effects as suggested by Hoetker (2007) referring to the continuous nature of the technological lead.

In our theoretical model, patenting and secrecy are mutually exclusive protection strategies. In contrast to this theoretical construct, many survey firms state the use of both patents and secrecy. There are several explanations for this observation, e.g., 
firms may conduct several innovation projects which they protect by different means. Alternatively, only parts of an invention may be patented, especially those which may be re-engineered easily. Following these arguments patenting and secrecy should not be seen as exclusive protection strategies. To take this into account, we define a new dependent variable and estimate a multinomial logit model using the following measure:

$$
\text { patent_secrecy }=\left\{\begin{array}{ll}
0 & \text { if patent }=0 \& \text { secrecy }=1 \\
1 & \text { if patent }=1 \& \text { secrecy }=0 \\
2 & \text { if patent }=1 \& \text { secrecy }=1
\end{array}\right\}
$$

with the base outcome 0. As, again, the interplay of technological lead and imperfect appropriability and its relation to the propensity to patent is a crucial part of the investigation of the disclosure effect, we analyze the interplay graphically in figure 4 .

A crucial assumption of the theoretical model is that the firms only conduct one innovation project. To account for this we include a robustness check by estimating the empirical models with a sample including only firms with less than 250 employees. In this reduced sample, firms should only have one (or only few) innovative product(s). ${ }^{11}$ The estimation results of the probit and the multinomial logit can be found in table 3 and in figures 3 and 4 .

A central result of the theoretical model is that the propensity to patent decreases with the technological lead (prediction 1). In line with the theoretical prediction, our empirical results display a negative sign of the respective marginal effect, but the overall effect of the technological lead turns out to be insignificant. ${ }^{12}$ Taking into account the fact that firms' intellectual property protection strategies possibly involve the combination of both protective measures, the results of the multinomial logit in table 3 allow us to draw a more accurate picture. Regarding the technological lead the multinomial logit reveals that using patenting as the only protection mechanism for innovative products is indeed negatively linked to the technological lead, whereas a positive relation is found for the contemporaneous use of patenting and secrecy. Both results are relative to the base category of choosing only secrecy. This finding is perfectly in line with prediction 1 . Our result may be interpreted in line with Hall and Harhoff (2012) who state that firms only disclose that part of an invention by patenting it, which can most easily be reengineered - as this is the part with the highest exposure to expropriation - and thereby try to omit the disclosure of essential know-how in their patents.

\footnotetext{
${ }^{11}$ We acknowledge that this robustness check can only be interpreted as an indicator for one-innovation firms. However, we are confident that the test is of relevance, as the emergence of multiple innovation projects should be positively correlated with the number of employees. Furthermore, we presume that small firms conduct research in technologically related areas meaning that the protection strategies as well as the respective competitive environments are most likely similar.

${ }^{12} \mathrm{~A}$ first tentative explanation for this finding could be that the theoretical model disregards several mandatory patentability requirements, e.g. a sufficiently high inventive step. Thus, while the model predicts that the propensity to patent is high whenever the technological lead is small, it actually may be the case that the respective extent of the technological headstart leading to a patent in theoretical terms, is de facto not eligible for patent protection as it does not incorporate a sufficient inventive step.
} 
The other central theoretical result regarding the disclosure effect and its impact on the propensity to patent is that in industries which are characterized by low appropriability via secrecy the initial technological lead may be reduced to such an extent that the propensity to patent increases (result 4). Empirically, we implement this effect by introducing an interaction term of technological lead and appropriability ( $T L * A P P)$ and analyze its relation to the propensity to patent. Our findings provide evidence that the empirical relation is in line with the theoretical result and thus support prediction 2. For the probit estimation, figure 3 shows graphically that in industries characterized by low appropriability, the relation between technological lead and the propensity to patent is positive. Figure 4 displays the results for the interaction term in the multinomial logit setting. We see that the alternative of protecting intellectual property only by patents relative to the alternative of only choosing secrecy exhibits no difference between firms in industries characterized by high or low appropriability. Thus, the effect of the interaction term is dominated by the negative link between technological lead and the propensity to use only patents. The multinomial logit allows us to account for a strategy mix, i.e. the contemporaneous use of patenting and secrecy, to protect newly generated knowledge. From figure 4, we can deduce that evidently a low appropriability and an increasing technological lead positively influence the joint use of patenting and secrecy. Finally, as suggested by theoretical result 4, appropriability itself displays no statistically significant relation with the propensity to patent.

$$
\begin{aligned}
& <\text { Insert figure } 3 \text { about here. }> \\
& <\text { Insert figure } 4 \text { about here. }>
\end{aligned}
$$

As a robustness check, we look at the reduced sample of firms with a maximum of 250 employees. We can confirm that our results also hold for this reduced sample Assuming that these firms most probably meet the theoretical assumption of one-product firms we are able to interpret our results as follows: In line with prediction 1 and 2, firms display a higher propensity to patent in situations in which their technological lead is low. A high technological lead may be associated with an increasing attractiveness of secrecy or a mixture of patenting and secrecy. Particularly, in environments in which the technological lead may be largely reduced by imperfect appropriability via secrecy, firms may opt for a mixture of patenting and secrecy as the relation between the propensity to use patenting and secrecy and the interaction term is significantly positive compared to the propensity to only use secrecy.

Turning to our control variables we can state that our results are in line with the stylized facts that the patenting behavior of firms as well as the joint use of patenting and secrecy is positively linked to the size of a firm, to its R\&D intensity, to R\&D subsidies 
as well as to the engagement of a firm in $\mathrm{R} \& \mathrm{D}$ cooperations. Interestingly, the control variables reflecting the strength of competition with respect to competitors, customers and regional dimensions are mainly insignificant. One exception is a significantly positive relation with non_EU. A possible explanation for this result is that firms which are inter alia active in non-EU markets tend to rate protection in their home-market as more important than firms operating solely in the German home-market. This effect may prevail due to the fact that those firms fear the entry of foreign firms with substitute products. Further, we find that R\&D cooperation has a positive significant link to the propensity to patent, whereas being located in Eastern Germany has a negative association. Generally, empirical evidence based on firm-level surveys finds that the propensity to patent varies by industry sectors. Our industry dummies are jointly significant hinting at structural differences between industry sectors.

\section{The protective effect of patenting}

Prediction 3 - regarding the protective effect of patenting - is tested by estimating an ordered probit with robust standard errors for the threat of entry by competitors. Again, marginal effects of the estimation on the timing of competitors' market entry are evaluated at the samples means and the respective standard errors are obtained using the delta method. The protective effect is represented by the extent of patent scope as described in Section 3.3. First, as the market structure and characteristics are surely linked to the competitors' timing of entry but at the same time are endogenous, we first estimate a basic model ignoring the specificities of the relevant market. Then we stepwise include the technology dimension of the relevant market and the competitive side. Furthermore, we conduct robustness checks $(i)$ estimating the model with a reduced sample of firms with not more than 250 employees, $(i i)$ altering the definition of patent scope, and (iii) using alternative measures for patent scope. The results including all robustness checks are displayed in tables 4 and 5 .

Table 4 shows the results of the ordered probit for the estimation of the threat of entry on patent scope. The findings are robust to variations $(i)-($ iii $)$ and confirm that a larger patent scope reflected by the number of delaying patents per 100 employees is negatively related to the threat of entry, implying that a reduced threat of entry is associated with larger patent scope. This finding is in line with prediction 3.

\section{$<$ Insert table 4 about here. $>$}

Robustness check $(i)$ is included in table 4 and the further robustness checks are provided in table 5 . For robustness check $(i i)$, we first moved the somewhat arbitrary separation of delaying and strongly protective patents to the left so that delaying patents are defined as patents with varying IPC codes at the level of Sections and Classes. Strongly protective patents are then defined by variations in Subclasses and Main Groups. Second, using this new limit between delaying and strongly protective patents we varied the frontier between strongly and weakly protective patents between Subclasses and 
Main Groups. All variations in the definition of delaying, strongly and weakly protective patents do not alter the previous results. The final robustness check (iii) using the number of forward citations per patent application as a measure for patent scope and additionally accounting for the number of patent applications per 100 employees shows that even using alternative measures of patent scope does not change our results concerning the protective effect of patenting as we find a negative link between citations and the threat of entry. Summarizing we can conclude that we find strong empirical evidence supporting prediction 3 that a larger patent scope is linked to a delayed market entry of competitors.

\section{$<$ Insert table 5 about here. $>$}

In contrast to the theoretical conjecture, we find no significant link of the competitor's market entry decision with the technological lead. Nevertheless, a positive relation with appropriability via secrecy is apparent. This is relatively intuitive as competitors benefit from the disclosure given imperfect appropriability. A positive relation can also be confirmed for quickly changing technologies and the number of firms in a market.

\section{Conclusion}

This paper provides an analysis of the decision to patent in light of the positive protective and the negative disclosure effect of patenting. By this the decision to patent is analyzed in the context of the competitive environment of firms. The first part of the paper is dedicated to a brief presentation of a theoretical model (Zaby, 2010b) from which we draw our testable predictions. In the second empirical part of the paper, we present empirical evidence for these predictions.

The theoretical model comes to the conclusion that while patenting may intensify the competitive threat perceived by an inventor due to the mandatory disclosure requirement, it may also mitigate the competitive threat by its protective effect. In the end, the predominant effect overcompensates the other, and thus, determines the decision to patent. We condense the theoretical results into three predictions reflecting the twofold effects of patenting. Predictions 1 and 2 refer to the disclosure effect, supposing that an increasing technological lead is negatively linked to the propensity to patent and that the appropriability via secrecy reduces even an initially high technological lead and thus displays a negative relation to the propensity to patent. To test these predictions we implement an interaction term of technological lead and appropriability.

Predictions 1 and 2 are tested looking at the propensity to patent. First, we directly translate the theoretical presumption and estimate a probit model of the decision patent vs. secrecy. The data, however, reveals that patenting and secrecy are not mutually exclusive which leads to a richer set of alternatives. This is transferred in empirical terms by estimating a multinomial logit accounting for three different protection strategies: 
the sole use of secrecy or patents and the joint use of patenting and secrecy. In the probit esimation, we do not find support for prediction 1. However, the multinomial logit provides an explanation: while the technological lead is negatively associated with the propensity to use only patenting to protect an innovation, the joint use of patenting and secrecy turns out to be positively associated with the technological lead. Both results support prediction 1 that an increasing technological lead is related to a decreasing propensity to patent. Both estimations - the probit and the multinomial logit - provide evidence supporting prediction 2 due to the fact that the effect of the interaction term is found to be positive and significant. The probit result - that a technological lead reduced by industry-specific imperfect appropriability is associated with an increasing propensity to patent - is confirmed by the multinomial logit result for the mixed protection strategy. If firms opt for patents as exclusive protection measure the link is reversed. The multinomial logit results thus allow us to draw a more detailed picture of the choice of protection strategies for innovative products.

Prediction 3 concerns the protective effect and states that an increasing patent scope decreases the threat of entry. To analyze prediction 3, we provide the results of an ordered probit estimation with respect to the threat of entry measured on a four-digit Likert scale. We interpret a lower threat of entry as an indicator that potential competitors postpone their market entry. To implement the differences in patent scope empirically, we build on previous work by Lerner (1994) and use the variations of IPC codes as a measure for the intensity of patent protection. In order to substantiate our results, we provide several robustness checks: We vary the definition of patent scope by implementing alternative frontiers for the different levels of protection based on the IPC classification. Furthermore, we use an alternative measure for patent scope based on forward citations. All results confirm prediction 3 and show that a low threat of entry is positively associated with the larger extent of patent scope.

Aside from the advancement of Lerner's measure for patent scope our main contribution is the containment of a stylized fact: We find that the common economic intuition that the propensity to patent is higher, the larger the technological advance an innovation embodies, actually only holds in industry sectors where appropriability via secrecy is imperfect. Thus, our theoretical finding that the propensity to patent decreases, the higher the technological lead of an innovator is, does not contradict common intuition but constrains its validity to industry sectors where the appropriability via secrecy is low.

Our empirical test suffers some limitations. First, the empirical translation of the theoretically identified core driving forces of the propensity to patent is not perfect particularly, imperfect appropriability via secrecy which is reflected by the easiness of substitutability. Although a close relation between both concepts exists in some circumstances this relation does not always hold, e.g. it is a valuable strategy for competitors to find adequate substitutes for an innovative product if its imitation is blocked by a patent (see e.g. Polidoro and Toh (2011)'s argumentation for the pharma industry). A possible remedy for this limitation would be to use shifts in patent legislation influencing the impact of disclosure requirements.

A further limitation of our analysis is that we do not take into account other strategic 
components of the patenting decision such as defensive motives. Finally, looking at oneproduct firms, our theoretical model allows for deeper insights at the level of innovation. The empirical data, however, only allow us to analyze the firm level. We try to heal this by providing evidence for small firms as they generally have only one innovation project or at least solely a limited number, and predominantly operate in one product market. However, we acknowledge that this is only a rough approximation of one-product firms. Information on specific innovation projects and the related protection strategies would be essential and would allow for a deeper understanding of the role of the countervailing effects of protection vs. disclosure on the patenting decision. 


\section{References}

\section{References}

Ai, C. and E. C. Norton (2003). Interaction terms in logit and probit models. Economics Letters 80, 123-129.

Anton, J. J. and D. A. Yao (2004). Little patents and big secrets: Managing intellectual property. RAND Journal of Economics 35(1), 1-22.

Arundel, A. (2001). The relative effectiveness of patents and secrecy for appropriation. Research Policy 30, 611-624.

Arundel, A. and I. Kabla (1998). What percentage of innovations are patented? Empirical estimatesfor european firms. Research Policy 27, 127-141.

Arundel, A., G. van de Paal, and L. Soete (1995). Innovation Strategies of Europe's Largest Industrial Firms. Results of thePACE Survey for Information Sources, Public Research, Protection of Innovationsand Government Programmes. Final Report, MERIT, PACE Report, Brussels.

Austin, D. H. (1993). An event-study approach to measuring innovative output: The case of biotechnology. American Economic Review Papers and Proceedings 83, 253-258.

Cohen, W., R. Nelson, and J. Walsh (2000). Protecting their intellectual assets: Appropriability conditions and why U. S. manufacturing firms patent (or not). NBER working paper 7552.

Denicolò, V. and P. Zanchettin (2002). How should forward patent protection be provided? International Journal of Industrial Organization 20, 801-827.

Dutta, P., S. Lach, and A. Rustichini (1995). Better late than early: Vertical differentiation in the adoption of a newtechnology. Journal of Economics $\&$ Management Strategy 4(4), 563-589.

Hall, B., A. Jaffe, and M. Trajtenberg (2005). Market value and patent citations. RAND Journal of Economics 36, 16-38.

Hall, B. H. and D. Harhoff (2012). Recent research on the economics of patents. NBER working paper 17 rym.

Harhoff, D., F. M. Scherer, and K. Vopel (2003). Citations, family size, opposition and the value of patent rights. Research Policy 32, 1343-1363.

Heger, D. and A. Zaby (2013). The heterogeneous costs of disclosure and the propensity to patent. Oxford Economic Papers, forthcoming. 
Hoetker, G. (2007). The use of logit and probit models in strategic management research: Critical issues. Strategic Management Journal 28, 331-343.

Hoppe, H. and U. Lehmann-Grube (2001). Second-mover advantages in dynamic quality competition. Journal of Economics \& Management Strategy 10(3), 419-433.

Horstmann, I., G. M. MacDonald, and A. Slivinsky (1985). Patents as information transfer mechanisms: to patent or (maybe) not topatent. Journal of Political Economy 93, 837-858.

Hussinger, K. (2006). Is silence golden? Patents versus secrecy at the firm level. Economics of Innovation and New Technology 15, 735-752.

König, H. and G. Licht (1995). Patents, R\&D and innovation: Evidence from the MannheimInnovation Panel. Ifo-Studien 33, 521-543.

Lerner, J. (1994). The importance of patent scope: An empirical analysis. RAND Journal of Economics 25, 319-333.

Polidoro, F. and P. Toh (2011). Letting rivals come close or warding them off? the effects of substitutionthreat on imitation deterrence. Academy of Management Journal 54, 369-392.

van Dijk, T. (1996). Patent height and competition in product improvements. The Journal of Industrial Economics 44, 151-167.

Zaby, A. K. (2010a). The decision to patent. Springer Heidelberg.

Zaby, A. K. (2010b). Losing the lead: The patenting decision in the light of the disclosure requirement. Economics of Innovation and New Technology 19, 147-164. 


\section{Figures}

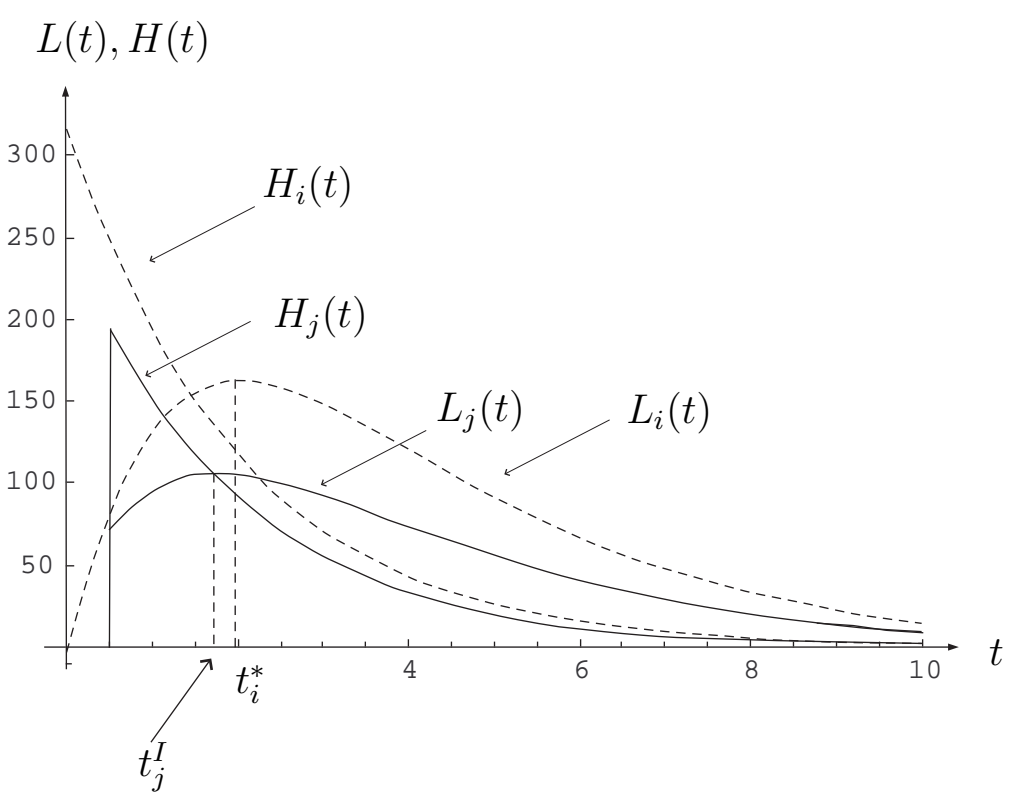

Figure 1: Overall profit functions for $\gamma=0.5$

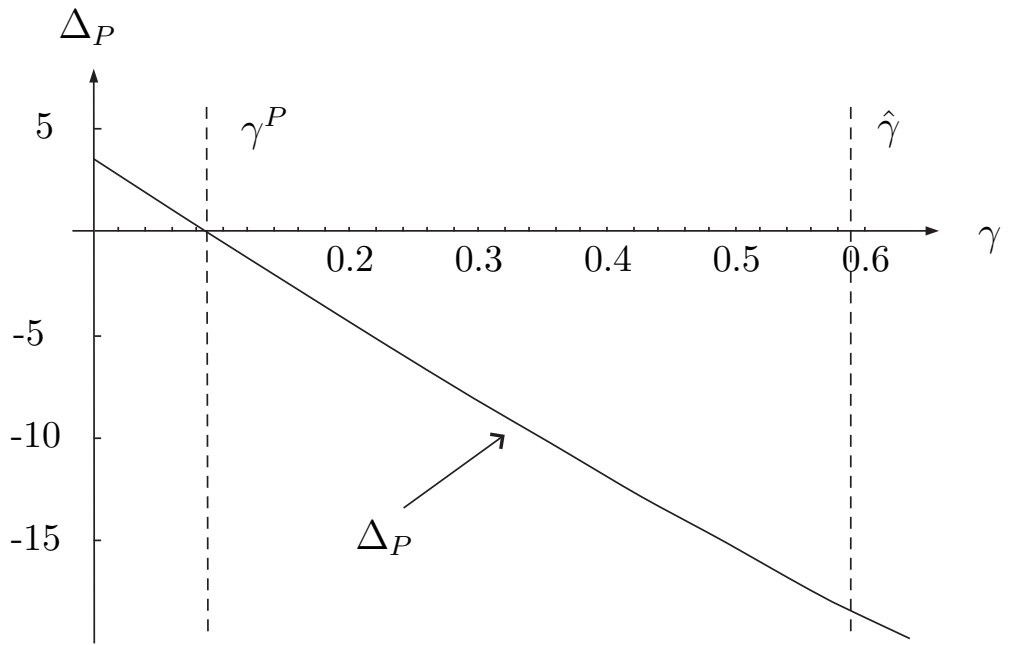

Figure 2: Total patent effect for $\phi=x_{l}^{i *}$ 


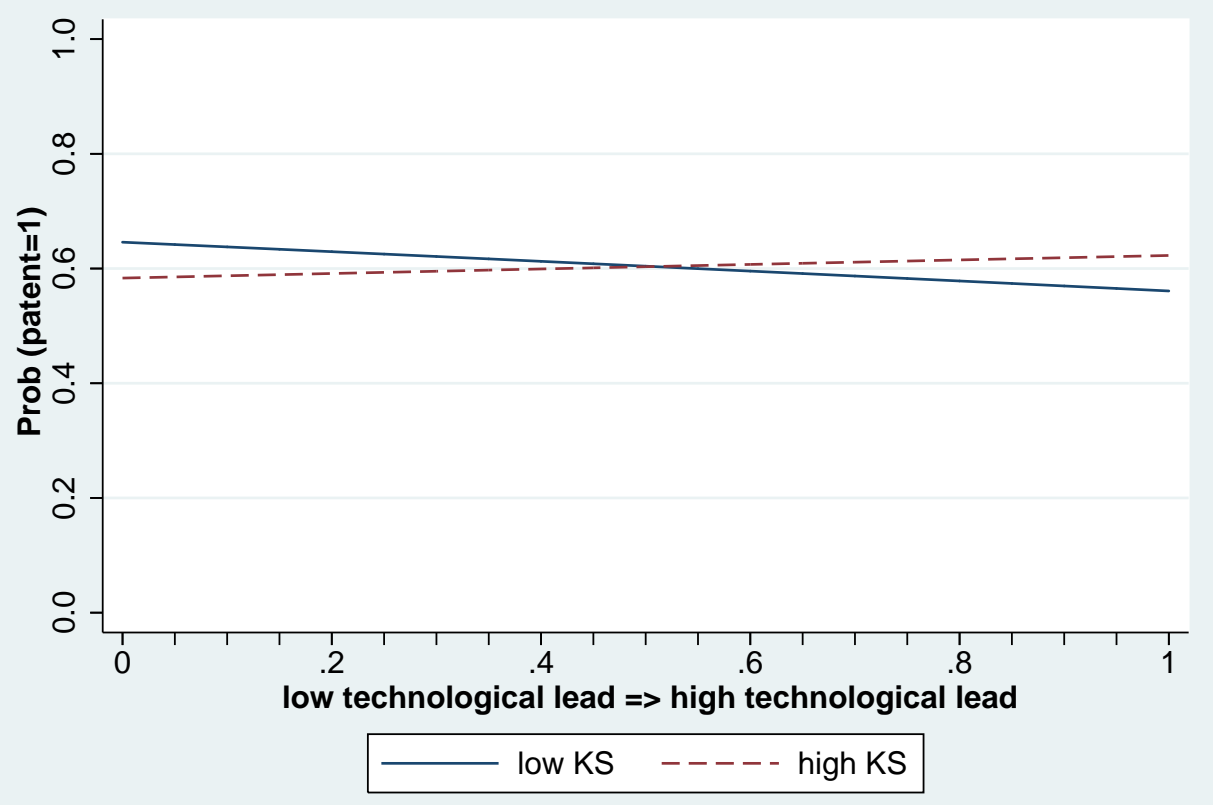

Firms with max. 250 employees

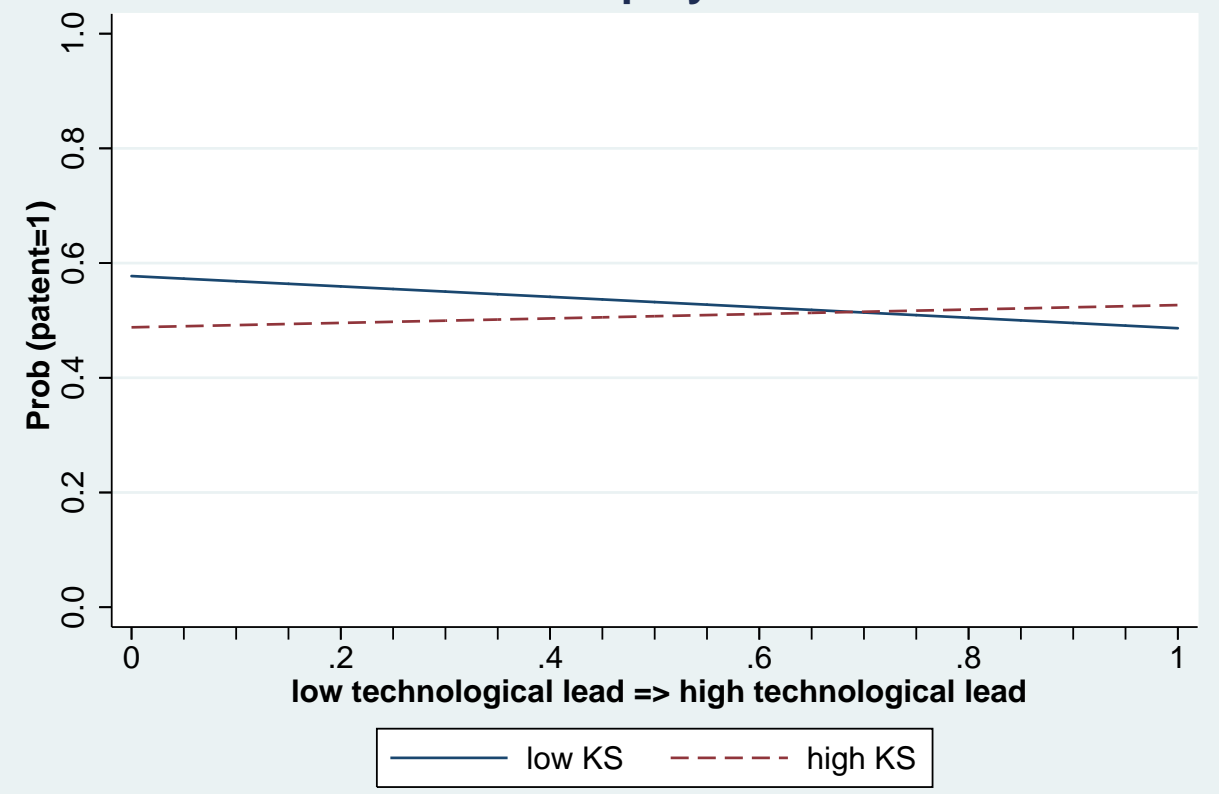

Figure 3: Relation of the propensity to patent with varying technological lead for different levels of the relevance of the embodied technology - probit estimation

Source: MIP 2005, authors' calculations.

Note: Average predictions for probit estimation. We look at two different levels of REL: 0 and 1 . 

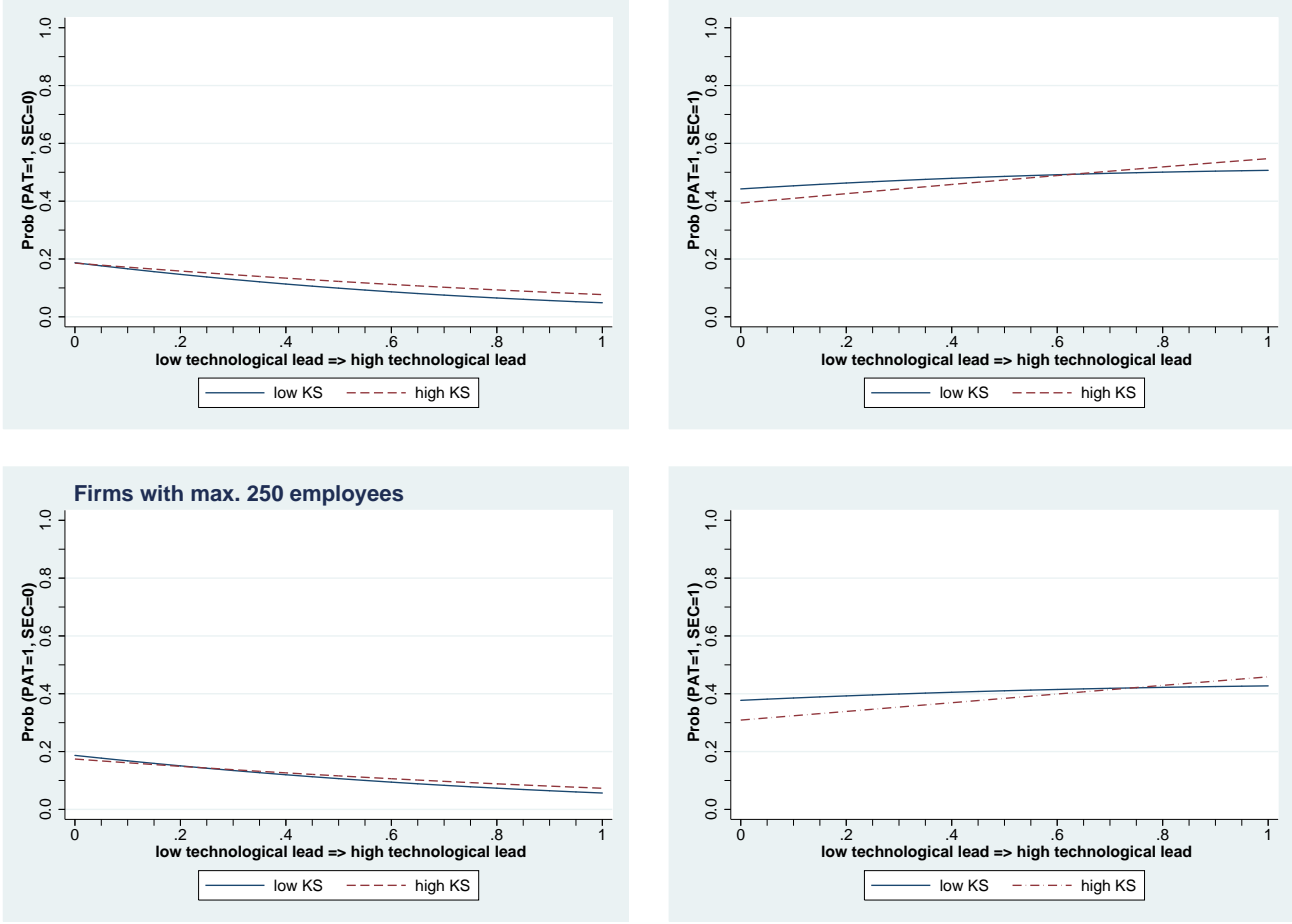

Figure 4: Relation of the patenting and secrecy with varying technological lead for different levels of the relevance of the embodied technology - multinomial logit estiamtion

Source: MIP 2005, authors' calculations.

Note: Average predictions for multinomial logit. We look at two different levels of REL: 0, and 1. 


\section{Tables}

Table 2: Descriptive Statistics

\begin{tabular}{|c|c|c|c|c|c|}
\hline & Mean & Std.Dev. & Min & $\operatorname{Max}$ & Description \\
\hline patent & 0.599 & 0.490 & 0 & 1 & $\begin{array}{l}\text { Patent application between } 2002 \text { and } \\
2004\end{array}$ \\
\hline secrecy & 0.885 & 0.320 & 0 & 1 & $\begin{array}{l}\text { Trade secrecy to protect innovation be- } \\
\text { tween } 2002 \text { and } 2004\end{array}$ \\
\hline technological lead & 0.594 & 0.491 & 0 & 1 & $\begin{array}{l}\text { Temporal headstart over competitors } \\
\text { highly important }\end{array}$ \\
\hline appropriability & 0.682 & 0.466 & 0 & 1 & $\begin{array}{l}\text { easy-to-substitute products in main } \\
\text { market fully or rather applies }\end{array}$ \\
\hline $\log ($ employees $)$ & 4.577 & 1.696 & 0.693 & 9.152 & Number of employees in 2002 \\
\hline human capital & 0.263 & 0.264 & 0.000 & 1.000 & $\begin{array}{l}\text { Share of employees holding a university } \\
\text { degree in } 2002\end{array}$ \\
\hline$R \mathscr{B} D$ intensity & 0.062 & 0.116 & 0.00 & 0.792 & $\begin{array}{l}\text { Expenditures for in-house R\&D per } \\
\text { sales in } 2003\end{array}$ \\
\hline cooperation & 0.455 & 0.498 & 0 & 1 & $\begin{array}{l}\text { Research cooperation with competi- } \\
\text { tors, customers, universities }\end{array}$ \\
\hline diversification & 0.657 & 0.244 & 0 & 1 & $\begin{array}{l}\text { sales share generatedby three most im- } \\
\text { portant customers }\end{array}$ \\
\hline subsidy & 0.418 & 0.493 & 0 & 1 & Public subsidies \\
\hline large no. of firms & 0.134 & 0.340 & 0 & 1 & $\begin{array}{l}\text { More than } 15 \text { competitors in main } \\
\text { market }\end{array}$ \\
\hline medium no. of firms & 0.204 & 0.403 & 0 & 1 & $\begin{array}{l}\text { Between } 6 \text { and } 15 \text { competitors in main } \\
\text { market }\end{array}$ \\
\hline product old & 0.091 & 0.287 & 0 & 1 & $\begin{array}{l}\text { competitive environment: products } \\
\text { rapidly obsolete (fully applies) }\end{array}$ \\
\hline tech. obsolete & 0.466 & 0.499 & 0 & 1 & $\begin{array}{l}\text { competitive environment: technolo- } \\
\text { gies change quickly (fully and rather } \\
\text { applies) }\end{array}$ \\
\hline$E U$ & 0.676 & 0.468 & 0 & 1 & $\begin{array}{l}\text { Main product market: EU without } \\
\text { Germany }\end{array}$ \\
\hline$n o n \_E U$ & 0.489 & 0.500 & 0 & 1 & main product market: outside EU \\
\hline east & 0.284 & 0.451 & 0 & 1 & Firm located in eastern Germany \\
\hline threat of entry & 1.455 & 0.767 & 0 & 3 & $\begin{array}{l}\text { Market position threatened by entry } \\
\text { ( } 3=\text { applies })\end{array}$ \\
\hline capital intensity & 0.089 & 0.144 & 0.000 & 1.575 & Tangible assets per employee in 2002 \\
\hline market novelty & 0.615 & 0.487 & 0 & 1 & Market novelty introduced XXX \\
\hline delaying & 0.171 & 0.572 & 0.000 & 4.505 & $\begin{array}{l}\text { No. of patents with delaying scope (per } \\
100 \text { employees) }\end{array}$ \\
\hline strongly protective & 0.028 & 0.121 & 0.000 & 1.066 & $\begin{array}{l}\text { No. of patents with large scope (per } \\
100 \text { employees) }\end{array}$ \\
\hline weakly protective & 0.062 & 0.237 & 0.000 & 2.041 & $\begin{array}{l}\text { No. of patents with small scope (per } \\
100 \text { employees) }\end{array}$ \\
\hline citations & 0.312 & 0.634 & 0.000 & 3.333 & No. of citations per patent \\
\hline patent stock & 0.564 & 1.600 & 0.000 & 13.993 & Patent stock per 100 employees \\
\hline $\mathrm{PAT}=1, \mathrm{SEC}=0$ & \multicolumn{5}{|c|}{$11.5 \%$} \\
\hline $\mathrm{PAT}=1, \mathrm{SEC}=1$ & \multicolumn{5}{|c|}{$48.4 \%$} \\
\hline $\mathrm{PAT}=0, \mathrm{SEC}=1$ & \multicolumn{5}{|c|}{$40.1 \%$} \\
\hline $\mathrm{PAT}=0, \mathrm{SEC}=0$ & \multicolumn{5}{|c|}{$00.0 \%$} \\
\hline No. of observations & \multicolumn{5}{|c|}{771} \\
\hline
\end{tabular}

Notes: The 11 industries we control for are ind1: Agriculture, Food, Textile; ind2: Mining, Coke, Fuel, Electricity; ind3: Wood, Paper, Publishing, Printing, Furniture, Recycling; ind4: Chemicals, Plastics, Glass; ind5: Metals; ind6: Machinery, Motor Vehicle without Aerospace; ind7: Office Machinery; ind8: Precision Instruments, Aerospace; ind9: Telecommunication and Computer Services; ind10: R\&D services; and ind11: Consumer-related Services like hotels, gastronomy. 
Table 3: Results of the Patenting Decision Estimation

\begin{tabular}{|c|c|c|c|c|c|c|}
\hline & \multicolumn{3}{|c|}{ all firms } & \multicolumn{3}{|c|}{ firms with $\leq 250$} \\
\hline & \multirow[t]{2}{*}{ Probit } & \multicolumn{2}{|c|}{ Multinomial Logit } & \multirow[t]{2}{*}{ Probit } & \multicolumn{2}{|c|}{ Multinomial Logit } \\
\hline & & $\mathrm{PAT}=1, \mathrm{SEC}=$ & $\mathrm{PAT}=1, \mathrm{SEC}=1$ & & $\mathrm{PAT}=1, \mathrm{SEC}=$ & $\mathrm{PAT}=1, \mathrm{SEC}=1$ \\
\hline & $\begin{array}{l}\text { Marg. Eff. } \\
\text { (Std. Err) }\end{array}$ & $\begin{array}{l}\text { Marg. Eff. } \\
\text { (Std. Err.) }\end{array}$ & $\begin{array}{l}\text { Marg. Eff. } \\
\text { (Std. Err.) }\end{array}$ & $\begin{array}{l}\text { Marg. Eff. } \\
\text { (Std. Err) }\end{array}$ & $\begin{array}{l}\text { Marg. Eff. } \\
\text { (Std. Err.) }\end{array}$ & $\begin{array}{l}\text { Marg. Eff. } \\
\text { (Std. Err.) }\end{array}$ \\
\hline technological lead & $\begin{array}{l}-0.071 \\
(0.060)\end{array}$ & $\begin{array}{l}-.060^{* * *} \\
(0.015)\end{array}$ & $\begin{array}{c}0.122^{* * *} \\
(0.046)\end{array}$ & $\begin{array}{l}-0.011 \\
(0.050)\end{array}$ & $\begin{array}{c}-0.033^{* * *} \\
(0.011)\end{array}$ & $\begin{array}{l}0.098^{*} \\
(0.052)\end{array}$ \\
\hline appropriability & $\begin{array}{l}-0.053 \\
(0.061)\end{array}$ & $\begin{array}{c}0.012 \\
(0.012)\end{array}$ & $\begin{array}{l}-0.010 \\
(0.051)\end{array}$ & $\begin{array}{l}-0.018 \\
(0.051)\end{array}$ & $\begin{array}{c}0.003 \\
(0.009)\end{array}$ & $\begin{array}{l}-0.018 \\
(0.056)\end{array}$ \\
\hline$T L * A P P$ & $\begin{array}{l}0.124^{*} \\
(0.070)\end{array}$ & & & $\begin{array}{c}0.130 \\
(0.085)\end{array}$ & & \\
\hline $\log$ (employees) & $\begin{array}{c}0.061 * * * \\
(0.011)\end{array}$ & $\begin{array}{l}-0.002 \\
(0.004)\end{array}$ & $\begin{array}{c}0.104 * * * \\
(0.017)\end{array}$ & $\begin{array}{c}0.072 * * * \\
(0.024)\end{array}$ & $\begin{array}{c}0.001 \\
(0.003)\end{array}$ & $\begin{array}{c}0.080^{* * *} \\
(0.026)\end{array}$ \\
\hline human capital & $\begin{array}{c}0.095 \\
(0.085)\end{array}$ & $\begin{array}{l}-0.051 \\
(0.033)\end{array}$ & $\begin{array}{l}0.239^{*} \\
(0.134)\end{array}$ & $\begin{array}{l}-0.017 \\
(0.125)\end{array}$ & $\begin{array}{l}-0.027 \\
(0.023)\end{array}$ & $\begin{array}{l}0.033 \\
(0.139)\end{array}$ \\
\hline Rछ'D intensity & $\begin{array}{c}0.667^{* * *} \\
(0.156)\end{array}$ & $\begin{array}{c}0.169^{* * *} \\
(0.049)\end{array}$ & $\begin{array}{c}0.993 * * * \\
(0.337)\end{array}$ & $\begin{array}{c}1.029^{* * *} \\
(0.291)\end{array}$ & $\begin{array}{c}0.120^{* * * *} \\
(0.032)\end{array}$ & $\begin{array}{c}0.986^{* * *} \\
(0.333)\end{array}$ \\
\hline cooperation & $\begin{array}{l}0.077^{*} \\
(0.040)\end{array}$ & $\begin{array}{l}-0.014 \\
(0.013)\end{array}$ & $\begin{array}{l}0.130 * * \\
(0.052)\end{array}$ & $\begin{array}{c}0.087 \\
(0.059)\end{array}$ & $\begin{array}{l}-0.008 \\
(0.010)\end{array}$ & $\begin{array}{l}0.123^{* *} \\
(0.062)\end{array}$ \\
\hline diversification & $\begin{array}{c}-0.134^{* *} \\
(0.065)\end{array}$ & $\begin{array}{l}-0.021 \\
(0.020)\end{array}$ & $\begin{array}{l}-0.139 \\
(0.093)\end{array}$ & $\begin{array}{c}-0.209^{* *} \\
(0.103)\end{array}$ & $\begin{array}{l}-0.023 \\
(0.014)\end{array}$ & $\begin{array}{l}-0.164 \\
(0.113)\end{array}$ \\
\hline subsidy & $\begin{array}{l}0.074^{*} \\
(0.040)\end{array}$ & $\begin{array}{l}-0.000 \\
(0.013)\end{array}$ & $\begin{array}{l}0.113^{* *} \\
(0.056)\end{array}$ & $\begin{array}{l}0.107^{*} \\
(0.061)\end{array}$ & $\begin{array}{l}0.000 \\
(0.010)\end{array}$ & $\begin{array}{l}0.116^{*} \\
(0.064)\end{array}$ \\
\hline large no. of firms & $\begin{array}{l}-0.067 \\
(0.048)\end{array}$ & $\begin{array}{l}-0.024 \\
(0.018)\end{array}$ & $\begin{array}{l}0.031 \\
(0.074)\end{array}$ & $\begin{array}{l}-0.097 \\
(0.076)\end{array}$ & $\begin{array}{l}-0.010 \\
(0.012)\end{array}$ & $\begin{array}{l}-0.058 \\
(0.086)\end{array}$ \\
\hline medium no. of firms & $\begin{array}{l}-0.011 \\
(0.042)\end{array}$ & $\begin{array}{l}0.004 \\
(0.013)\end{array}$ & $\begin{array}{l}-0.017 \\
(0.061)\end{array}$ & $\begin{array}{l}-0.008 \\
(0.063)\end{array}$ & $\begin{array}{c}0.003 \\
(0.009)\end{array}$ & $\begin{array}{l}-0.015 \\
(0.071)\end{array}$ \\
\hline product old & $\begin{array}{c}0.012 \\
(0.056)\end{array}$ & $\begin{array}{l}-0.045 \\
(0.032)\end{array}$ & $\begin{array}{c}0.056 \\
(0.081)\end{array}$ & $\begin{array}{l}0.001 \\
(0.084)\end{array}$ & $\begin{array}{l}-0.039 \\
(0.024)\end{array}$ & $\begin{array}{c}0.066 \\
(0.088)\end{array}$ \\
\hline tech. obsolete & $\begin{array}{l}-0.049 \\
(0.032)\end{array}$ & $\begin{array}{l}-0.014 \\
(0.011)\end{array}$ & $\begin{array}{l}-0.042 \\
(0.047)\end{array}$ & $\begin{array}{c}-0.101 * * \\
(0.049)\end{array}$ & $\begin{array}{l}-0.011 \\
(0.008)\end{array}$ & $\begin{array}{l}-0.082 \\
(0.055)\end{array}$ \\
\hline$E U$ & $\begin{array}{c}0.026 \\
(0.043)\end{array}$ & $\begin{array}{c}0.012 \\
(0.014)\end{array}$ & $\begin{array}{c}0.003 \\
(0.058)\end{array}$ & $\begin{array}{l}-0.023 \\
(0.059)\end{array}$ & $\begin{array}{l}0.001 \\
(0.009)\end{array}$ & $\begin{array}{l}-0.035 \\
(0.064)\end{array}$ \\
\hline$n o n_{-} E U$ & $\begin{array}{c}0.104^{* * *} \\
(0.038)\end{array}$ & $\begin{array}{c}0.003 \\
(0.011)\end{array}$ & $\begin{array}{c}0.132 * * * \\
(0.050)\end{array}$ & $\begin{array}{c}0.152^{* * *} \\
(0.055)\end{array}$ & $\begin{array}{c}0.007 \\
(0.008)\end{array}$ & $\begin{array}{c}0.149 * * \\
(0.060)\end{array}$ \\
\hline east & $\begin{array}{c}-0.093^{* *} \\
(0.039)\end{array}$ & $\begin{array}{c}0.007 \\
(0.012)\end{array}$ & $\begin{array}{c}-0.149 * * \\
(0.058)\end{array}$ & $\begin{array}{l}-0.064 \\
(0.054)\end{array}$ & $\begin{array}{l}-0.003 \\
(0.008)\end{array}$ & $\begin{array}{l}-0.060 \\
(0.060)\end{array}$ \\
\hline industry dummies & included & \multicolumn{2}{|c|}{ included } & included & \multicolumn{2}{|c|}{ included } \\
\hline Log likelihood & -394.35 & \multicolumn{2}{|c|}{-573.20} & -305.45 & \\
\hline McFadden's adjusted $R^{2}$ & 0.240 & \multicolumn{2}{|c|}{0.231} & 0.176 & \multicolumn{2}{|c|}{0.189} \\
\hline$\chi^{2}($ all $)$ & $194.97^{* * *}$ & \multirow{2}{*}{\multicolumn{2}{|c|}{$\begin{array}{l}2909.62^{* * *} \\
1066.02^{* * *}\end{array}$}} & $113.11^{* * *}$ & \multicolumn{2}{|c|}{$3061.68^{* * *}$} \\
\hline$\chi^{2}($ ind $)$ & $31.26^{* * *}$ & & & 13.69 & \multirow{2}{*}{\multicolumn{2}{|c|}{$\begin{array}{c}2015.12^{* * *} \\
535\end{array}$}} \\
\hline No. of observations & 771 & \multicolumn{2}{|c|}{771} & 535 & & \\
\hline
\end{tabular}

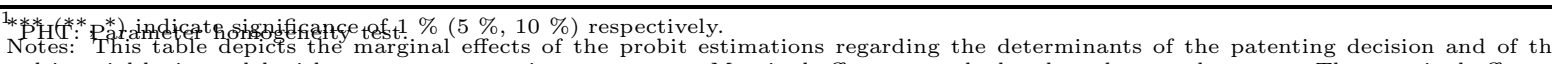
multinomial logit model with respect to patenting vs. secrecy. Marginal effects are calculated at the sample means. The marginal effect of
the probit's interaction term is obtained according to Ai and Norton (2003) and analyzes graphically (see Figures 3 and 4). Standard errors are calculated with the delta method.
are centition of the industry dummies can be found in the notes of Table $2 . \quad \chi^{2}($ all $)$ displays a test on the joint significance of all variables. 
Table 4: Ordered Probit for Threat of Entry Estimation

Basic Model

Technology

Competition

Firms with $\leq \mathbf{2 5 0}$

\begin{tabular}{|c|c|c|c|c|c|c|c|c|c|c|c|c|c|c|c|c|}
\hline threat & strong & medium & weak & no & strong & medium & weak & no & strong & medium & weak & no & strong & medium & weak & \\
\hline delaying & $\begin{array}{c}-0.034^{* *} \\
(0.015)\end{array}$ & $\begin{array}{c}-0.047^{* *} \\
(0.020)\end{array}$ & $\begin{array}{l}0.051 * * \\
(0.023)\end{array}$ & $\begin{array}{l}0.030^{* *} \\
(0.012)\end{array}$ & $\begin{array}{c}-0.035^{* *} \\
(0.015)\end{array}$ & $\begin{array}{c}-0.048^{* *} \\
(0.020)\end{array}$ & $\begin{array}{l}0.052^{* *} \\
(0.022)\end{array}$ & $\begin{array}{l}0.031^{* *} \\
(0.010)\end{array}$ & $\begin{array}{c}-0.029^{* *} \\
(0.014)\end{array}$ & $\begin{array}{c}-0.040^{* *} \\
(0.019)\end{array}$ & $\begin{array}{l}.043 * * \\
(0.021)\end{array}$ & $\begin{array}{l}0.026^{* *} \\
(0.012)\end{array}$ & $\begin{array}{c}-0.033^{* *} \\
(0.016)\end{array}$ & $\begin{array}{c}-0.049^{* *} \\
(0.022)\end{array}$ & $\begin{array}{l}0.056^{* *} \\
(0.026)\end{array}$ & $(0.011)$ \\
\hline strongly prot. & $\begin{array}{l}0.022 \\
(0.061)\end{array}$ & $\begin{array}{c}0.030 \\
(0.085)\end{array}$ & $\begin{array}{l}-0.032 \\
(0.092)\end{array}$ & $\begin{array}{l}-0.019 \\
(0.054)\end{array}$ & $\begin{array}{c}0.039 \\
(0.058)\end{array}$ & $\begin{array}{c}0.054 \\
(0.087)\end{array}$ & $\begin{array}{l}-0.059 \\
(0.086)\end{array}$ & $\begin{array}{l}-0.035 \\
(0.052)\end{array}$ & $\begin{array}{l}0.049 \\
(0.053)\end{array}$ & $\begin{array}{l}0.068 \\
(0.075)\end{array}$ & $\begin{array}{l}-0.074 \\
(0.080)\end{array}$ & $\begin{array}{l}-0.044 \\
(0.048)\end{array}$ & $\begin{array}{c}0.053 \\
(0.087)\end{array}$ & $\begin{array}{l}0.078 \\
(0.131)\end{array}$ & $\begin{array}{l}-0.090 \\
(0.149)\end{array}$ & \\
\hline weakly prot. & $\begin{array}{c}0.020 \\
(0.048)\end{array}$ & $\begin{array}{c}0.028 \\
(0.066)\end{array}$ & $\begin{array}{l}-0.031 \\
(0.072)\end{array}$ & $\begin{array}{l}-0.018 \\
(0.042)\end{array}$ & $\begin{array}{c}0.003 \\
(0.047)\end{array}$ & $\begin{array}{c}0.036 \\
(0.065)\end{array}$ & $\begin{array}{l}-0.003 \\
(0.070)\end{array}$ & $\begin{array}{l}-0.002 \\
(0.041)\end{array}$ & $\begin{array}{l}-0.001 \\
(0.044)\end{array}$ & $\begin{array}{l}-0.002 \\
(0.061)\end{array}$ & $\begin{array}{c}0.002 \\
(0.066)\end{array}$ & $\begin{array}{c}0.001 \\
(0.039)\end{array}$ & $\begin{array}{l}-0.003 \\
(0.069)\end{array}$ & $\begin{array}{l}-0.004 \\
(0.102)\end{array}$ & $\begin{array}{c}0.005 \\
(0.118)\end{array}$ & \\
\hline tech. lead & $\begin{array}{c}0.007 \\
(0.016)\end{array}$ & $\begin{array}{c}0.010 \\
(0.023)\end{array}$ & $\begin{array}{l}-0.011 \\
(0.025)\end{array}$ & $\begin{array}{l}-0.007 \\
(0.015)\end{array}$ & $\begin{array}{c}0.006 \\
(0.016)\end{array}$ & $\begin{array}{l}0.007 \\
(0.023)\end{array}$ & $\begin{array}{l}-0.007 \\
(0.025)\end{array}$ & $\begin{array}{l}-0.004 \\
(0.014)\end{array}$ & $\begin{array}{c}0.006 \\
(0.016)\end{array}$ & $\begin{array}{c}0.009 \\
(0.022)\end{array}$ & $\begin{array}{l}-0.009 \\
(0.024)\end{array}$ & $\begin{array}{l}-0.006 \\
(0.014)\end{array}$ & $\begin{array}{c}0.004 \\
(0.019)\end{array}$ & $\begin{array}{c}0.006 \\
(0.028)\end{array}$ & $\begin{array}{l}-0.007 \\
(0.032)\end{array}$ & \\
\hline$A P P$ & $\begin{array}{c}0.053 * * * \\
(0.018)\end{array}$ & $\begin{array}{c}0.073^{* * *} \\
(0.022)\end{array}$ & $\begin{array}{c}-0.079 * * * \\
(0.025)\end{array}$ & $\begin{array}{c}-0.046^{* * *} \\
(0.015)\end{array}$ & $\begin{array}{c}0.059^{* * * *} \\
(0.018)\end{array}$ & $\begin{array}{c}0.082^{* * *} \\
(0.023)\end{array}$ & $\begin{array}{c}-0.089^{* * *} \\
(0.025)\end{array}$ & $\begin{array}{c}-0.056^{* * *} \\
(0.016)\end{array}$ & $\begin{array}{c}0.078^{* * *} \\
(0.018)\end{array}$ & $\begin{array}{c}0.078^{* * *} \\
(0.022)\end{array}$ & $\begin{array}{c}-0.084^{* * *} \\
(0.025)\end{array}$ & $\begin{array}{c}-0.050^{* * *} \\
(0.016)\end{array}$ & $\begin{array}{l}0.052^{* *} \\
(0.020)\end{array}$ & $\begin{array}{c}0.077^{* * *} \\
(0.027)\end{array}$ & $\begin{array}{c}-0.088^{* * *} \\
(0.032)\end{array}$ & \\
\hline $\log (e m p)$. & $\begin{array}{c}0.004 \\
(0.006)\end{array}$ & $\begin{array}{c}0.006 \\
(0.008)\end{array}$ & $\begin{array}{c}-0.006 \\
(0.009)\end{array}$ & $\begin{array}{l}-0.004 \\
(0.005)\end{array}$ & $\begin{array}{c}0.007 \\
(0.006)\end{array}$ & $\begin{array}{c}0.005 \\
(0.008)\end{array}$ & $\begin{array}{c}-0.007 \\
(0.009)\end{array}$ & $\begin{array}{l}-0.004 \\
(0.005)\end{array}$ & $\begin{array}{c}0.003 \\
(0.006)\end{array}$ & $\begin{array}{c}0.004 \\
(0.008)\end{array}$ & $\begin{array}{l}-0.004 \\
(0.008)\end{array}$ & $\begin{array}{l}-0.002 \\
(0.005)\end{array}$ & $\begin{array}{c}0.011 \\
(0.009)\end{array}$ & $\begin{array}{c}0.017 \\
(0.013)\end{array}$ & $\begin{array}{l}-0.019 \\
(0.015)\end{array}$ & \\
\hline cap. intensity & $\begin{array}{l}-0.050 \\
(0.055)\end{array}$ & $\begin{array}{l}-0.069 \\
(0.077)\end{array}$ & $\begin{array}{c}0.075 \\
(0.083)\end{array}$ & $\begin{array}{c}0.044 \\
(0.048)\end{array}$ & $\begin{array}{l}-0.033 \\
(0.055)\end{array}$ & $\begin{array}{l}-0.045 \\
(0.076)\end{array}$ & $\begin{array}{l}0.049 \\
(0.083)\end{array}$ & $\begin{array}{l}0.029 \\
(0.048)\end{array}$ & $\begin{array}{l}-0.029 \\
(0.053)\end{array}$ & $\begin{array}{l}-0.040 \\
(0.075)\end{array}$ & $\begin{array}{c}0.043 \\
(0.081)\end{array}$ & $\begin{array}{l}0.025 \\
(0.048)\end{array}$ & $\begin{array}{l}-0.045 \\
(0.096)\end{array}$ & $\begin{array}{l}-0.067 \\
(0.141)\end{array}$ & $\begin{array}{c}0.077 \\
(0.163)\end{array}$ & \\
\hline cooperation & $\begin{array}{l}-0.020 \\
(0.016)\end{array}$ & $\begin{array}{l}-0.028 \\
(0.022)\end{array}$ & $\begin{array}{l}0.030 \\
(0.024)\end{array}$ & $\begin{array}{c}0.018 \\
(0.014)\end{array}$ & $\begin{array}{l}-0.019 \\
(0.016)\end{array}$ & $\begin{array}{l}-0.027 \\
(0.021)\end{array}$ & $\begin{array}{l}0.029 \\
(0.023)\end{array}$ & $\begin{array}{l}0.017 \\
(0.014)\end{array}$ & $\begin{array}{l}-0.011 \\
(0.015)\end{array}$ & $\begin{array}{l}-0.016 \\
(0.021)\end{array}$ & $\begin{array}{l}0.017 \\
(0.023)\end{array}$ & $\begin{array}{c}0.010 \\
(0.014)\end{array}$ & $\begin{array}{l}-0.027 \\
(0.019)\end{array}$ & $\begin{array}{l}-0.040 \\
(0.027)\end{array}$ & $\begin{array}{c}0.047 \\
(0.032)\end{array}$ & \\
\hline market novelty & $\begin{array}{l}-0.024 \\
(0.017)\end{array}$ & $\begin{array}{l}-0.036 \\
(0.023)\end{array}$ & $\begin{array}{c}0.040 \\
(0.025)\end{array}$ & $\begin{array}{l}0.023 \\
(0.015)\end{array}$ & $\begin{array}{l}-0.021 \\
(0.017)\end{array}$ & $\begin{array}{l}-0.030 \\
(0.024)\end{array}$ & $\begin{array}{c}0.030 \\
(0.023)\end{array}$ & $\begin{array}{l}0.021 \\
(0.015)\end{array}$ & $\begin{array}{l}-0.022 \\
(0.017)\end{array}$ & $\begin{array}{l}-0.030 \\
(0.024)\end{array}$ & $\begin{array}{c}0.033 \\
(0.025)\end{array}$ & $\begin{array}{l}0.019 \\
(0.015)\end{array}$ & $\begin{array}{l}-0.001 \\
(0.020)\end{array}$ & $\begin{array}{l}-0.001 \\
(0.030)\end{array}$ & $\begin{array}{l}0.001 \\
(0.035)\end{array}$ & \\
\hline diversification & $\begin{array}{c}0.023 \\
(0.033)\end{array}$ & $\begin{array}{c}0.032 \\
(0.045)\end{array}$ & $\begin{array}{l}-0.034 \\
(0.049)\end{array}$ & $\begin{array}{l}-0.020 \\
(0.028)\end{array}$ & $\begin{array}{c}0.025 \\
(0.033)\end{array}$ & $\begin{array}{c}0.033 \\
(0.024)\end{array}$ & $\begin{array}{l}-0.037 \\
(0.049)\end{array}$ & $\begin{array}{l}-0.022 \\
(0.028)\end{array}$ & $\begin{array}{c}0.025 \\
(0.032)\end{array}$ & $\begin{array}{c}0.034 \\
(0.044)\end{array}$ & $\begin{array}{l}-0.037 \\
(0.048)\end{array}$ & $\begin{array}{l}-0.022 \\
(0.028)\end{array}$ & $\begin{array}{c}0.028 \\
(0.037)\end{array}$ & $\begin{array}{c}0.042 \\
(0.053)\end{array}$ & $\begin{array}{l}-0.048 \\
(0.061)\end{array}$ & \\
\hline large \# of firms & & & & & & & & & $\begin{array}{l}0.052 * * \\
(0.025)\end{array}$ & $\begin{array}{c}0.072^{* * *} \\
(0.033)\end{array}$ & $\begin{array}{c}-0.078^{* *} \\
(0.037)\end{array}$ & $\begin{array}{c}-0.046^{* *} \\
(0.022)\end{array}$ & $\begin{array}{c}0.045 \\
(0.030)\end{array}$ & $\begin{array}{c}0.067 \\
(0.043)\end{array}$ & $\begin{array}{l}-0.077 \\
(0.051)\end{array}$ & \\
\hline med. \# of firms & & & & & & & & & $\begin{array}{c}0.066^{* * * *} \\
(0.020)\end{array}$ & $\begin{array}{c}0.092 * * * \\
(0.026)\end{array}$ & $\begin{array}{c}-0.099^{* * *} * \\
(0.029)\end{array}$ & $\begin{array}{c}-0.059^{* * *} \\
(0.018)\end{array}$ & $\begin{array}{l}0.058 * * \\
(0.023)\end{array}$ & $\begin{array}{c}0.086^{* * *} \\
(0.032)\end{array}$ & $\begin{array}{c}-0.099^{* * * *} \\
(0.037)\end{array}$ & \\
\hline product old & & & & & $\begin{array}{c}0.036 \\
(0.024)\end{array}$ & $\begin{array}{c}0.050 \\
(0.034)\end{array}$ & $\begin{array}{l}-0.055 \\
(0.036)\end{array}$ & $\begin{array}{l}-0.032 \\
(0.022)\end{array}$ & $\begin{array}{c}0.039 \\
(0.024)\end{array}$ & $\begin{array}{c}0.055 \\
(0.034)\end{array}$ & $\begin{array}{c}-0.059 \\
(0.036)\end{array}$ & $\begin{array}{c}-0.035 \\
(0.022)\end{array}$ & $\begin{array}{c}0.022 \\
(0.025)\end{array}$ & $\begin{array}{c}0.032 \\
(0.038)\end{array}$ & $\begin{array}{l}-0.037 \\
(0.043)\end{array}$ & \\
\hline tech. obsolete & & & & & $\begin{array}{c}0.056 * * * \\
(0.017)\end{array}$ & $\begin{array}{c}0.078^{* * *} \\
(0.022)\end{array}$ & $\begin{array}{c}-0.085^{* * *} \\
(0.024)\end{array}$ & $\begin{array}{c}-0.049^{* * *} \\
(0.015)\end{array}$ & $\begin{array}{c}0.056 * * * \\
(0.017)\end{array}$ & $\begin{array}{c}0.078^{* * *} \\
(0.022)\end{array}$ & $\begin{array}{c}-0.085^{* * *} \\
(0.024)\end{array}$ & $\begin{array}{c}-0.050^{* * * *} \\
(0.015)\end{array}$ & $\begin{array}{l}0.052^{* * *} \\
(0.020)\end{array}$ & $\begin{array}{c}0.077^{* * *} \\
(0.028)\end{array}$ & $\begin{array}{c}-0.088^{* * * *} \\
(0.032)\end{array}$ & \\
\hline$E U$ & & & & & & & & & $\begin{array}{l}-0.008 \\
(0.021)\end{array}$ & $\begin{array}{l}-0.11 \\
(0.028)\end{array}$ & $\begin{array}{c}0.012 \\
(0.031)\end{array}$ & $\begin{array}{l}0.007 \\
(0.018)\end{array}$ & $\begin{array}{l}-0.011 \\
(0.023)\end{array}$ & $\begin{array}{l}-0.016 \\
(0.033)\end{array}$ & $\begin{array}{c}0.019 \\
(0.038)\end{array}$ & \\
\hline non_E $U$ & & & & & & & & & $\begin{array}{l}-0.006 \\
(0.018)\end{array}$ & $\begin{array}{l}-0.009 \\
(0.025)\end{array}$ & $\begin{array}{c}0.010 \\
(0.027)\end{array}$ & $\begin{array}{l}0.006 \\
(0.016)\end{array}$ & $\begin{array}{l}0.003 \\
(0.021)\end{array}$ & $\begin{array}{l}0.004 \\
(0.030)\end{array}$ & $\begin{array}{l}-0.004 \\
(0.035)\end{array}$ & $(0.6$ \\
\hline east & $\begin{array}{l}0.021 \\
(0.017)\end{array}$ & $\begin{array}{l}0.028 \\
(0.024)\end{array}$ & $\begin{array}{l}-0.031 \\
(0.025)\end{array}$ & $\begin{array}{l}-0.018 \\
(0.015)\end{array}$ & $\begin{array}{l}0.017 \\
(0.017)\end{array}$ & $\begin{array}{c}0.023 \\
(0.024)\end{array}$ & $\begin{array}{l}-0.025 \\
(0.026)\end{array}$ & $\begin{array}{l}-0.015 \\
(0.015)\end{array}$ & $\begin{array}{l}0.010 \\
(0.017)\end{array}$ & $\begin{array}{c}0.014 \\
(0.024)\end{array}$ & $\begin{array}{l}-0.015 \\
(0.025)\end{array}$ & $\begin{array}{l}-0.009 \\
(0.015)\end{array}$ & $\begin{array}{l}0.014 \\
(0.018)\end{array}$ & $\begin{array}{l}0.021 \\
(0.027)\end{array}$ & $\begin{array}{l}-0.024 \\
(0.030)\end{array}$ & $\begin{array}{l}-0.8 \\
(0.0\end{array}$ \\
\hline industries & \multicolumn{4}{|c|}{ included } & \multicolumn{4}{|c|}{ included } & \multicolumn{4}{|c|}{ included } & \multicolumn{4}{|c|}{ included } \\
\hline Log likelihood & \multirow{2}{*}{\multicolumn{4}{|c|}{$\begin{array}{c}-571.82 \\
0.032\end{array}$}} & \multirow{2}{*}{\multicolumn{4}{|c|}{-563.72}} & \multirow{2}{*}{\multicolumn{4}{|c|}{$\begin{array}{c}-556.33 \\
0.058\end{array}$}} & \multirow{2}{*}{\multicolumn{4}{|c|}{-369.05}} \\
\hline Adj. $R^{2}$ & & & & & & & & & & & & & \multirow{2}{*}{\multicolumn{4}{|c|}{$\begin{array}{c}0.054 \\
48.48^{* * *}\end{array}$}} \\
\hline$\chi^{2}($ all $)$ & \multicolumn{4}{|c|}{$40.16^{* * *}$} & \multicolumn{4}{|c|}{$\begin{array}{c}0.045 \\
60.99^{* * *}\end{array}$} & \multicolumn{4}{|c|}{$\begin{array}{l}0.058 \\
80.99^{* * *}\end{array}$} & & & & \\
\hline$\chi^{2}($ ind $)$ & \multirow{2}{*}{\multicolumn{4}{|c|}{$\begin{array}{c}13.78 \\
527\end{array}$}} & \multirow{2}{*}{\multicolumn{4}{|c|}{14.73}} & \multirow{2}{*}{\multicolumn{4}{|c|}{$\begin{array}{c}17.16^{*} \\
527\end{array}$}} & \multicolumn{4}{|c|}{10.43} \\
\hline No. of obs. & & & & & & & & & & & & & \multicolumn{3}{|c|}{$\begin{array}{c}10.43 \\
360\end{array}$} & \\
\hline
\end{tabular}

*** $(* * *)$ indicate significance of $1 \%(5 \%, 10 \%)$ respectively.
This table depicts marginal effects for an ordered probit for the estimation of threat of entry. Marginal effects are calculated at the sample means and standard errors are calculated with the delta method. The effect the interaction term is included in the overall effects of its components technologicallead and knowledgespillover.
Adj. $R^{2}$ is equivalent to McFadden's adj. $R^{2}$.

$\chi_{2}^{2}($ all $)$ displays a test on the joint significance of all variables. 
Table 5: Ordered Probit for Threat of Entry Estimation - Robustness Checks

\begin{tabular}{|c|c|c|c|c|c|c|c|c|c|c|c|c|}
\hline \multirow[b]{2}{*}{ threat } & \multicolumn{4}{|c|}{ new delaying def. } & \multicolumn{4}{|c|}{ new strongly protective def. } & \multicolumn{4}{|c|}{ Citations } \\
\hline & strong & medium & weak & no & strong & medium & weak & no & strong & medium & weak & no \\
\hline delaying & $\begin{array}{c}-0.029^{* *} \\
(0.014)\end{array}$ & $\begin{array}{c}-0.040^{* *} \\
(0.019)\end{array}$ & $\begin{array}{l}0.043^{* *} \\
(0.021)\end{array}$ & $\begin{array}{l}0.025^{* *} \\
(0.012)\end{array}$ & $\begin{array}{c}-0.030^{* *} \\
(0.014)\end{array}$ & $\begin{array}{c}-0.041^{* *} \\
(0.019)\end{array}$ & $\begin{array}{l}0.045^{* *} \\
(0.021)\end{array}$ & $\begin{array}{l}0.026^{* *} \\
(0.012)\end{array}$ & & & & \\
\hline strongly protective & $\begin{array}{c}0.025 \\
(0.044)\end{array}$ & $\begin{array}{c}0.035 \\
(0.062)\end{array}$ & $\begin{array}{l}-0.037 \\
(0.066)\end{array}$ & $\begin{array}{l}-0.022 \\
(0.040)\end{array}$ & $\begin{array}{l}-0.018 \\
(0.087)\end{array}$ & $\begin{array}{l}-0.024 \\
(0.120)\end{array}$ & $\begin{array}{c}0.026 \\
(0.130)\end{array}$ & $\begin{array}{c}0.016 \\
(0.077)\end{array}$ & & & & \\
\hline weakly protective & $\begin{array}{l}-0.004 \\
(0.046)\end{array}$ & $\begin{array}{l}-0.006 \\
(0.063)\end{array}$ & $\begin{array}{l}0.007 \\
(0.068)\end{array}$ & $\begin{array}{c}0.004 \\
(0.041)\end{array}$ & $\begin{array}{c}0.016 \\
(0.029)\end{array}$ & $\begin{array}{c}0.023 \\
(0.041)\end{array}$ & $\begin{array}{l}-0.024 \\
(0.044)\end{array}$ & $\begin{array}{l}-0.014 \\
(0.026)\end{array}$ & & & & \\
\hline citations & & & & & & & & & $\begin{array}{l}-0.025^{*} \\
(0.014)\end{array}$ & $\begin{array}{l}-0.034^{*} \\
(0.018)\end{array}$ & $\begin{array}{l}0.037^{*} \\
(0.020)\end{array}$ & $\begin{array}{l}0.022^{*} \\
(0.012)\end{array}$ \\
\hline patent stock & & & & & & & & & $\begin{array}{l}0.160 \\
(0.429)\end{array}$ & $\begin{array}{l}0.215 \\
(0.577)\end{array}$ & $\begin{array}{l}-0.233 \\
(0.623)\end{array}$ & $\begin{array}{l}-0.142 \\
(0.383)\end{array}$ \\
\hline technological lead & $\begin{array}{l}0.006 \\
(0.016)\end{array}$ & $\begin{array}{c}0.009 \\
(0.022)\end{array}$ & $\begin{array}{l}-0.010 \\
(0.024)\end{array}$ & $\begin{array}{l}-0.006 \\
(0.014)\end{array}$ & $\begin{array}{l}0.007 \\
(0.016)\end{array}$ & $\begin{array}{c}0.009 \\
(0.022)\end{array}$ & $\begin{array}{l}-0.010 \\
(0.024)\end{array}$ & $\begin{array}{l}-0.006 \\
(0.014)\end{array}$ & $\begin{array}{c}0.007 \\
(0.016)\end{array}$ & $\begin{array}{c}0.013 \\
(0.022)\end{array}$ & $\begin{array}{l}-0.010 \\
(0.023)\end{array}$ & $\begin{array}{l}-0.010 \\
(0.016)\end{array}$ \\
\hline appropriability & $\begin{array}{c}0.056^{* * * *} \\
(0.018)\end{array}$ & $\begin{array}{c}0.078^{* * *} \\
(0.023)\end{array}$ & $\begin{array}{c}-0.084^{* * * *} \\
(0.025)\end{array}$ & $\begin{array}{c}-0.050 * * * \\
(0.016)\end{array}$ & $\begin{array}{c}0.056^{* * *} \\
(0.018)\end{array}$ & $\begin{array}{c}0.077^{* * *} \\
(0.023)\end{array}$ & $\begin{array}{c}-0.084^{* * *} \\
(0.025)\end{array}$ & $\begin{array}{c}-0.050^{* * * *} \\
(0.016)\end{array}$ & $\begin{array}{c}0.055 * * * \\
(0.015)\end{array}$ & $\begin{array}{c}0.086 * * * \\
(0.024)\end{array}$ & $\begin{array}{c}-0.082^{* * * *} \\
(0.021)\end{array}$ & $\begin{array}{c}-0.059 * * * \\
(0.018)\end{array}$ \\
\hline $\log ($ employees $)$ & $\begin{array}{c}0.003 \\
(0.006)\end{array}$ & $\begin{array}{c}0.004 \\
(0.008)\end{array}$ & $\begin{array}{c}-0.004 \\
(0.008)\end{array}$ & $\begin{array}{l}-0.002 \\
(0.005)\end{array}$ & $\begin{array}{c}0.003 \\
(0.006)\end{array}$ & $\begin{array}{c}0.004 \\
(0.008)\end{array}$ & $\begin{array}{l}-0.004 \\
(0.008)\end{array}$ & $\begin{array}{l}-0.002 \\
(0.005)\end{array}$ & $\begin{array}{c}0.005 \\
(0.006)\end{array}$ & $\begin{array}{l}0.007 \\
(0.008)\end{array}$ & $\begin{array}{c}-0.007 \\
(0.008)\end{array}$ & $\begin{array}{l}-0.004 \\
(0.005)\end{array}$ \\
\hline capital intensity & $\begin{array}{l}-0.028 \\
(0.053)\end{array}$ & $\begin{array}{l}-0.039 \\
(0.075)\end{array}$ & $\begin{array}{l}0.042 \\
(0.080)\end{array}$ & $\begin{array}{c}0.025 \\
(0.048)\end{array}$ & $\begin{array}{l}-0.029 \\
(0.053)\end{array}$ & $\begin{array}{l}-0.041 \\
(0.075)\end{array}$ & $\begin{array}{c}0.044 \\
(0.081)\end{array}$ & $\begin{array}{c}0.026 \\
(0.048)\end{array}$ & $\begin{array}{l}-0.028 \\
(0.054)\end{array}$ & $\begin{array}{l}-0.038 \\
(0.073)\end{array}$ & $\begin{array}{c}0.041 \\
(0.078)\end{array}$ & $\begin{array}{l}0.025 \\
(0.048)\end{array}$ \\
\hline cooperation & $\begin{array}{l}-0.012 \\
(0.015)\end{array}$ & $\begin{array}{l}-0.017 \\
(0.021)\end{array}$ & $\begin{array}{c}0.018 \\
(0.023)\end{array}$ & $\begin{array}{c}0.011 \\
(0.014)\end{array}$ & $\begin{array}{l}-0.009 \\
(0.015)\end{array}$ & $\begin{array}{l}-0.017 \\
(0.021)\end{array}$ & $\begin{array}{c}0.018 \\
(0.023)\end{array}$ & $\begin{array}{c}0.011 \\
(0.014)\end{array}$ & $\begin{array}{l}-0.014 \\
(0.016)\end{array}$ & $\begin{array}{l}-0.019 \\
(0.021)\end{array}$ & $\begin{array}{c}0.020 \\
(0.022)\end{array}$ & $\begin{array}{c}0.012 \\
(0.014)\end{array}$ \\
\hline market novelty & $\begin{array}{l}-0.022 \\
(0.017)\end{array}$ & $\begin{array}{l}-0.030 \\
(0.024)\end{array}$ & $\begin{array}{c}0.033 \\
(0.025)\end{array}$ & $\begin{array}{c}0.019 \\
(0.015)\end{array}$ & $\begin{array}{l}-0.012 \\
(0.015)\end{array}$ & $\begin{array}{l}-0.031 \\
(0.024)\end{array}$ & $\begin{array}{c}0.033 \\
(0.025)\end{array}$ & $\begin{array}{c}0.020 \\
(0.015)\end{array}$ & $\begin{array}{l}-0.017 \\
(0.017)\end{array}$ & $\begin{array}{l}-0.022 \\
(0.023)\end{array}$ & $\begin{array}{c}0.024 \\
(0.025)\end{array}$ & $\begin{array}{c}0.015 \\
(0.015)\end{array}$ \\
\hline diversification & $\begin{array}{l}0.024 \\
(0.032)\end{array}$ & $\begin{array}{c}0.034 \\
(0.044)\end{array}$ & $\begin{array}{l}-0.037 \\
(0.048)\end{array}$ & $\begin{array}{l}-0.022 \\
(0.028)\end{array}$ & $\begin{array}{l}0.025 \\
(0.032)\end{array}$ & $\begin{array}{c}0.035 \\
(0.044)\end{array}$ & $\begin{array}{l}-0.037 \\
(0.048)\end{array}$ & $\begin{array}{l}-0.022 \\
(0.028)\end{array}$ & $\begin{array}{c}0.021 \\
(0.032)\end{array}$ & $\begin{array}{l}0.028 \\
(0.043)\end{array}$ & $\begin{array}{l}-0.030 \\
(0.046)\end{array}$ & $\begin{array}{l}-0.018 \\
(0.028)\end{array}$ \\
\hline large no. of firms & $\begin{array}{l}0.052^{* *} \\
(0.025)\end{array}$ & $\begin{array}{c}0.072^{* *} \\
(0.033)\end{array}$ & $\begin{array}{c}-0.078^{* *} \\
(0.037)\end{array}$ & $\begin{array}{c}-0.046^{* *} \\
(0.022)\end{array}$ & $\begin{array}{l}0.051^{* *} \\
(0.025)\end{array}$ & $\begin{array}{l}0.072^{* *} \\
(0.033)\end{array}$ & $\begin{array}{c}-0.077^{* *} \\
(0.037)\end{array}$ & $\begin{array}{c}-0.046^{* *} \\
(0.022)\end{array}$ & $\begin{array}{l}0.048^{*} \\
(0.025)\end{array}$ & $\begin{array}{l}0.064^{* *} \\
(0.032)\end{array}$ & $\begin{array}{c}-0.070^{* *} \\
(0.036)\end{array}$ & $\begin{array}{c}-0.043^{*} \\
(0.022)\end{array}$ \\
\hline medium no. of firms & $\begin{array}{c}0.066 * * * \\
(0.020)\end{array}$ & $\begin{array}{c}0.092^{* * * *} \\
(0.026)\end{array}$ & $\begin{array}{c}-0.099^{* * * *} \\
(0.029)\end{array}$ & $\begin{array}{c}-0.059^{* * *} \\
(0.018)\end{array}$ & $\begin{array}{c}0.066 * * * \\
(0.020)\end{array}$ & $\begin{array}{c}0.092^{* * *} \\
(0.026)\end{array}$ & $\begin{array}{c}-0.099^{* * * *} \\
(0.029)\end{array}$ & $\begin{array}{c}-0.059^{* * * *} \\
(0.018)\end{array}$ & $\begin{array}{c}0.055 * * * \\
(0.020)\end{array}$ & $\begin{array}{c}0.075 * * * \\
(0.026)\end{array}$ & $\begin{array}{c}-0.081^{* * *} \\
(0.028)\end{array}$ & $\begin{array}{c}-0.049^{* * *} \\
(0.018)\end{array}$ \\
\hline product old & $\begin{array}{l}0.040^{*} \\
(0.024)\end{array}$ & $\begin{array}{l}0.055 \\
(0.034)\end{array}$ & $\begin{array}{c}-0.060^{*} \\
(0.036)\end{array}$ & $\begin{array}{l}-0.035 \\
(0.022)\end{array}$ & $\begin{array}{l}0.040^{*} \\
(0.024)\end{array}$ & $\begin{array}{c}0.056 \\
(0.034)\end{array}$ & $\begin{array}{c}-0.060^{*} \\
(0.036)\end{array}$ & $\begin{array}{l}-0.036 \\
(0.022)\end{array}$ & $\begin{array}{c}0.037 \\
(0.023)\end{array}$ & $\begin{array}{c}0.050 \\
(0.031)\end{array}$ & $\begin{array}{c}-0.054 \\
(0.033)\end{array}$ & $\begin{array}{l}-0.033 \\
(0.021)\end{array}$ \\
\hline tech. obsolete & $\begin{array}{c}0.056^{* * * *} \\
(0.017)\end{array}$ & $\begin{array}{c}0.078^{* * * *} \\
(0.022)\end{array}$ & $\begin{array}{c}-0.085^{* * *} \\
(0.024)\end{array}$ & $\begin{array}{c}-0.050^{* * *} \\
(0.016)\end{array}$ & $\begin{array}{c}0.056^{* * * *} \\
(0.017)\end{array}$ & $\begin{array}{c}0.077^{* * *} \\
(0.022)\end{array}$ & $\begin{array}{c}-0.084^{* * *} \\
(0.024)\end{array}$ & $\begin{array}{c}-0.050^{* * * *} \\
(0.015)\end{array}$ & $\begin{array}{c}0.057 * * * \\
(0.017)\end{array}$ & $\begin{array}{c}0.077 * * * \\
(0.022)\end{array}$ & $\begin{array}{c}-0.083^{* * *} \\
(0.023)\end{array}$ & $\begin{array}{c}-0.051^{* * *} \\
(0.016)\end{array}$ \\
\hline$E U$ & $\begin{array}{l}-0.008 \\
(0.021)\end{array}$ & $\begin{array}{l}-0.011 \\
(0.028)\end{array}$ & $\begin{array}{l}0.011 \\
(0.031)\end{array}$ & $\begin{array}{l}0.007 \\
(0.018)\end{array}$ & $\begin{array}{l}-0.007 \\
(0.021)\end{array}$ & $\begin{array}{l}-0.011 \\
(0.028)\end{array}$ & $\begin{array}{c}0.012 \\
(0.031)\end{array}$ & $\begin{array}{c}0.007 \\
(0.018)\end{array}$ & $\begin{array}{l}-0.008 \\
(0.021)\end{array}$ & $\begin{array}{l}-0.010 \\
(0.028)\end{array}$ & $\begin{array}{c}0.011 \\
(0.030)\end{array}$ & $\begin{array}{l}0.007 \\
(0.019)\end{array}$ \\
\hline non_EU & $\begin{array}{l}-0.007 \\
(0.018)\end{array}$ & $\begin{array}{l}-0.009 \\
(0.025)\end{array}$ & $\begin{array}{l}0.010 \\
(0.027)\end{array}$ & $\begin{array}{l}0.006 \\
(0.016)\end{array}$ & $\begin{array}{l}-0.008 \\
(0.021)\end{array}$ & $\begin{array}{l}-0.009 \\
(0.025)\end{array}$ & $\begin{array}{c}0.009 \\
(0.027)\end{array}$ & $\begin{array}{l}0.006 \\
(0.016)\end{array}$ & $\begin{array}{l}-0.015 \\
(0.018)\end{array}$ & $\begin{array}{l}-0.020 \\
(0.024)\end{array}$ & $\begin{array}{c}0.022 \\
(0.026)\end{array}$ & $\begin{array}{l}0.013 \\
(0.016)\end{array}$ \\
\hline east & $\begin{array}{l}0.011 \\
(0.017)\end{array}$ & $\begin{array}{l}0.015 \\
(0.024)\end{array}$ & $\begin{array}{l}-0.016 \\
(0.026)\end{array}$ & $\begin{array}{l}-0.009 \\
(0.015)\end{array}$ & $\begin{array}{l}0.010 \\
(0.017)\end{array}$ & $\begin{array}{c}0.013 \\
(0.024)\end{array}$ & $\begin{array}{l}-0.014 \\
(0.025)\end{array}$ & $\begin{array}{l}-0.009 \\
(0.015)\end{array}$ & $\begin{array}{c}0.006 \\
(0.017)\end{array}$ & $\begin{array}{l}0.008 \\
(0.023)\end{array}$ & $\begin{array}{l}-0.009 \\
(0.025)\end{array}$ & $\begin{array}{l}-0.005 \\
(0.016)\end{array}$ \\
\hline industry dummies & \multicolumn{4}{|c|}{ included } & \multicolumn{4}{|c|}{ included } & \multicolumn{4}{|c|}{ included } \\
\hline Log likelihood & \multicolumn{4}{|c|}{-556.42} & \multicolumn{4}{|c|}{-556.42} & \multicolumn{4}{|c|}{-572.28} \\
\hline McFadden's adjusted $R^{2}$ & \multirow{2}{*}{\multicolumn{4}{|c|}{$\begin{array}{c}0.058 \\
79.10^{* * *}\end{array}$}} & \multicolumn{4}{|c|}{0.058} & \multicolumn{4}{|c|}{0.055} \\
\hline$\chi^{2}($ all $)$ & & & & & \multirow{2}{*}{\multicolumn{4}{|c|}{$\begin{array}{c}80.42^{* * *} \\
17.09^{*}\end{array}$}} & \multicolumn{4}{|c|}{$73.15^{* * *}$} \\
\hline$\chi^{2}($ ind $)$ & \multicolumn{4}{|c|}{$17.03^{*}$} & & & & & \multirow{2}{*}{\multicolumn{4}{|c|}{539}} \\
\hline No. of observations & \multicolumn{4}{|c|}{527} & \multicolumn{4}{|c|}{527} & & & & \\
\hline
\end{tabular}

*** $(* * *)$ indicate significance of $1 \%(5 \%, 10 \%)$ respectively.
This table depicts marginal effects for an ordered probit for the estimation of threat of entry. Marginal effects are calculated at the sample means and standard errors are calculated This table depicts marginal effects for an ordered probit for the estimation of threat of entry. Marginal effects are calculated at the sample means and stand
with the delta method. The effect of the interaction term is included in the overall effects of its components technologicallead and knowledgespillover.
$\chi_{2}^{2}$ (all) displays a test on the joint significance of all variables.

with (all dedisplays a test on the joint significance of all variables.
$\chi^{2}($ ind $)$ displays a test on the joint significance of the industry dummies. 